This PDF is a selection from an out-of-print volume from the National Bureau of Economic Research

Volume Title: Regional and Global Capital Flows: Macroeconomic Causes and Consequences, NBER-EASE Volume 10

Volume Author/Editor: Takatoshi Ito and Anne O. Krueger, editors

Volume Publisher: University of Chicago Press

Volume ISBN: 0-226-38676-7

Volume URL: http://www.nber.org/books/ito_01-1

Publication Date: January 2001

Chapter Title: How Were Capital Inflows Stimulated under the Dollar Peg System?

Chapter Authors: Eiji Ogawa, Lijian Sun

Chapter URL: http://www.nber.org/chapters/c10734

Chapter pages in book: (p. $151-190)$ 


\section{How Were Capital Inflows \\ Stimulated under the \\ Dollar Peg System?}

Eiji Ogawa and Lijian Sun

\subsection{Introduction}

The Asian currency crisis that started in Thailand in July 1997 had spread rapidly to other Association of Southeast Asian Nations (ASEAN) countries and the Newly Industrializing Economies (NIES) in Asia. Among the affected nations, Thailand, Indonesia, and Korea faced the most severe currency crises. Their governments requested financial support from the International Monetary Fund (IMF).

It is commonly stated that the Asian currency crisis had the following features (IMF 1997c, 1998; Ito 1999). First, the monetary authorities of the affected countries adopted an exchange rate policy of pegging the domestic currency to the U.S. dollar with an extremely large weight. The de facto dollar peg system influenced both the nation's current and capital accounts. An appreciation of the U.S. dollar had worsened the current accounts under the de facto dollar peg system since May $1995 .{ }^{1}$ De facto dollar pegging also made domestic borrowers and foreign lenders ignore the risk of foreign exchange.

Second, macroeconomic variables, except for large current account deficits in Thailand, Malaysia, and Korea, were in sustainable condition before the crisis. Neither budget deficits nor decreases in foreign reserves

Eiji Ogawa is professor of commerce at Hitotsubashi University. Lijian Sun is associate professor of international finance at Fudan University, Shanghai.

We appreciate Takatoshi Ito, Francis T. Lui, Pranee Tinakorn, Carmen Reinhart, Toshiki Jinushi, and a referee for their useful comments and suggestions. We also appreciate the help of Yukiko Takase (Economic Planning Agency) for providing us the statistical data. Ogawa received a grant from the Japan Securities Scholarship Foundation.

1. Ito, Ogawa, and Sasaki (1998) calculated an optimal weight of currency basket for stabilizing trade balances. 
were found-especially as compared to the past currency crises in Latin America. Although growth rates of export revenues had abruptly gone down in these countries since 1996, the large amounts of capital inflows made the governments complacent about their current account deficits.

Lastly, the currency crisis occurred simultaneously with a financial crisis which made some financial intermediaries go bankrupt. The IMF (1997c, 1998) pointed out that in the background of the financial crisis, there was a fragile financial sector. In an effort to prevent further deterioration, the IMF required the governments of the various countries to restructure their financial sectors as conditionality for receiving financial support. Large capital inflows to the countries with inadequate financial institutions brought about the financial crisis.

According to Kaminsky, Lizondo, and Reinhart (1997), there seems to be a consistent relationship between financial and currency crises in emerging market countries. Indeed, in the past, currency crisis often occurred along with financial crisis. The literature on financial and currency crises has been classified into three groups. The first group (Velasco 1987; Dooley 1997; Calvo and Mendoza 1996) explains that a financial crisis brings about a currency crisis, whereas the second group (IMF 1997b; Miller 1996) explains that a currency crisis causes a financial crisis. The third group (Calvo, Leiderman, and Reinhart 1993; Goldfajn and Valdes 1997) accounts for the possibility of a common external factor that brings about both the financial and currency crises at the same time-e.g., fluctuations of the world interest rate that influenced the flow of international capital to and from the domestic financial markets triggered the Mexico crisis in 1994.

This paper places emphasis on external factors as the cause of currency and financial crises. It focuses on fluctuations of the exchange rate under the de facto dollar peg system. In the 1990s, there were large swings of the yen against the U.S. dollar; the yen rapidly appreciated during the early 1990s and depreciated after 1995. If the monetary authorities of a country were to adopt a dollar peg system, the fluctuations in the exchange rate of the yen against the U.S. dollar would have caused the same fluctuations in the exchange rate of the yen against the relevant currencies.

This paper empirically analyzes how the de facto dollar peg system adversely influenced capital inflows to the countries in crisis by studying the relationship between the de facto dollar peg system and the capital inflows to these countries. Focus is placed on countries that requested IMF financial support during the Asian crisis, namely, Thailand, Korea, and Indonesia. We regress capital flows on explanatory variables such as interest rates, foreign exchange risks, export growth rate, and rate of change in stock prices. We then use an instrumental variable method to take into account how the instrumental variables are influenced by other variables.

The estimated regression equations are then used to conduct a simula- 
tion analysis of how the capital inflows would have behaved had the monetary authorities of these countries adopted a currency basket peg system instead of the de facto dollar peg system. The currency basket peg system would have increased fluctuations in the exchange rate of the domestic currency against the U.S. dollar, whereas it would have decreased the fluctuations of the exchange rate against the yen. Accordingly, a currency basket peg system would have changed the actual and the expected changes in exchange rates, and led to a change in foreign exchange risks.

The simulation analysis generates the following results: A currency basket peg system would have had a depressing effect on capital inflows to Thailand and Korea during the analyzed period 1985-96. It would also have had a slightly depressing effect on capital inflows to Indonesia. Increases in foreign exchange risk against the U.S. dollar under a currency basket peg system would have contributed most to the depressing effect. This is because the estimated foreign exchange risk variable against the U.S. dollar is the most significant variable among the explanatory variables in the capital flow equation.

This paper is organized as follows. Section 5.2 gives an overview of how different variables influence capital inflows to the Asian countries before the crisis. In section 5.3, a simple model of capital inflows that consists of a capital flow equation with instrumental variables is set up. An instrumental variable method is then used to estimate the capital flow equation. We drop the instrumental variables that have a coefficient with the wrong sign and proceed to estimate the regression equations. In section 5.4, the estimated regression equations are used to conduct a simulation analysis of the capital inflows under the currency basket peg system. Simulated values under the currency basket peg system are compared with estimated values under the actual de facto dollar peg system. The simulation shows how the dollar peg system influenced the capital inflows to these countries and how a currency basket peg system would have influenced them. Finally, we summarize analytical results and conclude in section 5.5.

\subsection{Capital Inflows before the Asian Currency Crisis}

According to the classification by the IMF (1997a), before the crisis, the Asian countries with currencies attacked by speculation in 1997 had in fact adopted exchange rate arrangements other than the dollar peg system. The exchange rate arrangements in Indonesia, Malaysia, and Korea were classified as the managed float system. The exchange rate arrangement in the Philippines was classified as an independent float system. The exchange rate system in Thailand was described as a basket peg system. Hong Kong was the only one under the dollar peg system in the IMF's classification.

However, research by Frankel and Wei (1994), Kawai and Akiyama (1998), and Kawai (1997) on the currency to which the monetary authori- 
Table 5.1 Weights on the Dollar and the Yen in Exchange Rate Policies of Asian Countries

\begin{tabular}{lccccr}
\hline & \multicolumn{2}{c}{ Sample Period 1979-92 } & & \multicolumn{2}{c}{ Sample Period 1990-96 } \\
\cline { 2 - 3 } \cline { 5 - 6 } $\begin{array}{l}\text { Coefficient on } \\
\text { the Dollar }\end{array}$ & $\begin{array}{c}\text { Coefficient on } \\
\text { the Yen }\end{array}$ & & $\begin{array}{c}\text { Coefficient on } \\
\text { the Dollar }\end{array}$ & $\begin{array}{r}\text { Coefficient } \\
\text { on the Yen }\end{array}$ \\
\hline Singapore & 0.75 & 0.13 & & $0.420^{\mathrm{a}}$ & 0.021 \\
Hong Kong & 0.92 & -0.00 & & 1.002 & -0.002 \\
Korea & 0.96 & -0.10 & & 0.941 & 0.088 \\
Malaysia & 0.78 & 0.07 & & 0.589 & 0.044 \\
Thailand & 0.91 & 0.05 & & 0.789 & 0.104 \\
The Philippines & 1.07 & -0.01 & & 1.087 & -0.094 \\
Indonesia & 0.95 & 0.16 & & 0.966 & 0.014 \\
\hline
\end{tabular}

Sources: Frankel and Wei (1994); Kawai (1997).

${ }^{\mathrm{a} C o e f f i c i e n t}$ on the SDR is 0.600 .

ties of the Asian countries pegged their currencies suggests otherwise. Frankel and Wei (1994) estimated the weights placed on major foreign currencies in their exchange rate policy during the period 1979-92. Kawai (1997) also estimated them during the period 1990-96 using the same method as Frankel and Wei. The result of estimation is summarized in table 5.1. For example, the weight on the U.S. dollar is 0.91 (Frankel and Wei 1994) and 0.789 (Kawai 1997) for Thailand. The weight placed on the U.S. dollar is nearly equal to one for Korea and Indonesia. Thus, the estimation indicates that these three countries have indeed adopted the de facto dollar peg system.

Next, we examine fluctuation of the exchange rates of these currencies against the U.S. dollar and the yen under the de facto dollar peg system. Figure 5.1 shows movements in the exchange rates of the Asian currencies against the U.S. dollar in the 1990s. The exchange rates in terms of the U.S. dollar were relatively stable until July 1997. The Thai baht and the Hong Kong dollar had been kept almost stable since 1990. The Malaysian ringgit had been kept relatively stable although it had been perfectly pegged to the U.S. dollar. The Korean won also had been kept relatively stable. The Indonesian rupiah had been changing at a predictable and constant rate because the monetary authorities had adopted a crawling peg to the U.S. dollar.

Figure 5.2 shows movements in the exchange rates of these currencies in terms of the yen. The exchange rates in terms of the yen underwent more substantial fluctuations compared to those against the U.S. dollar. Although they had a tendency to depreciate against the yen from 1990 to 1995, all of the currencies have been appreciating against it since May 1995. The joint movements of the exchange rates in terms of the yen were attributed to the de facto dollar peg system. 


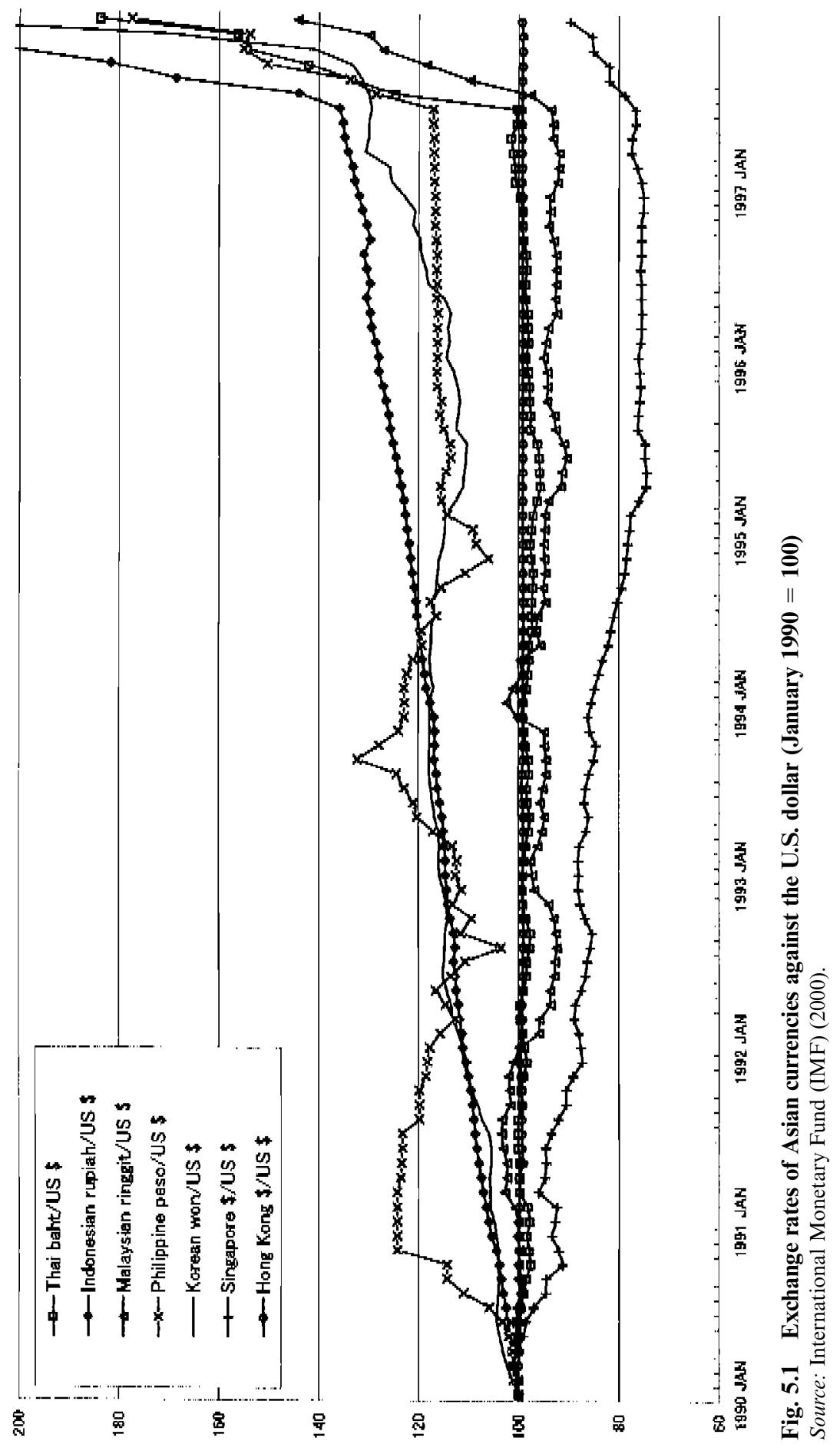




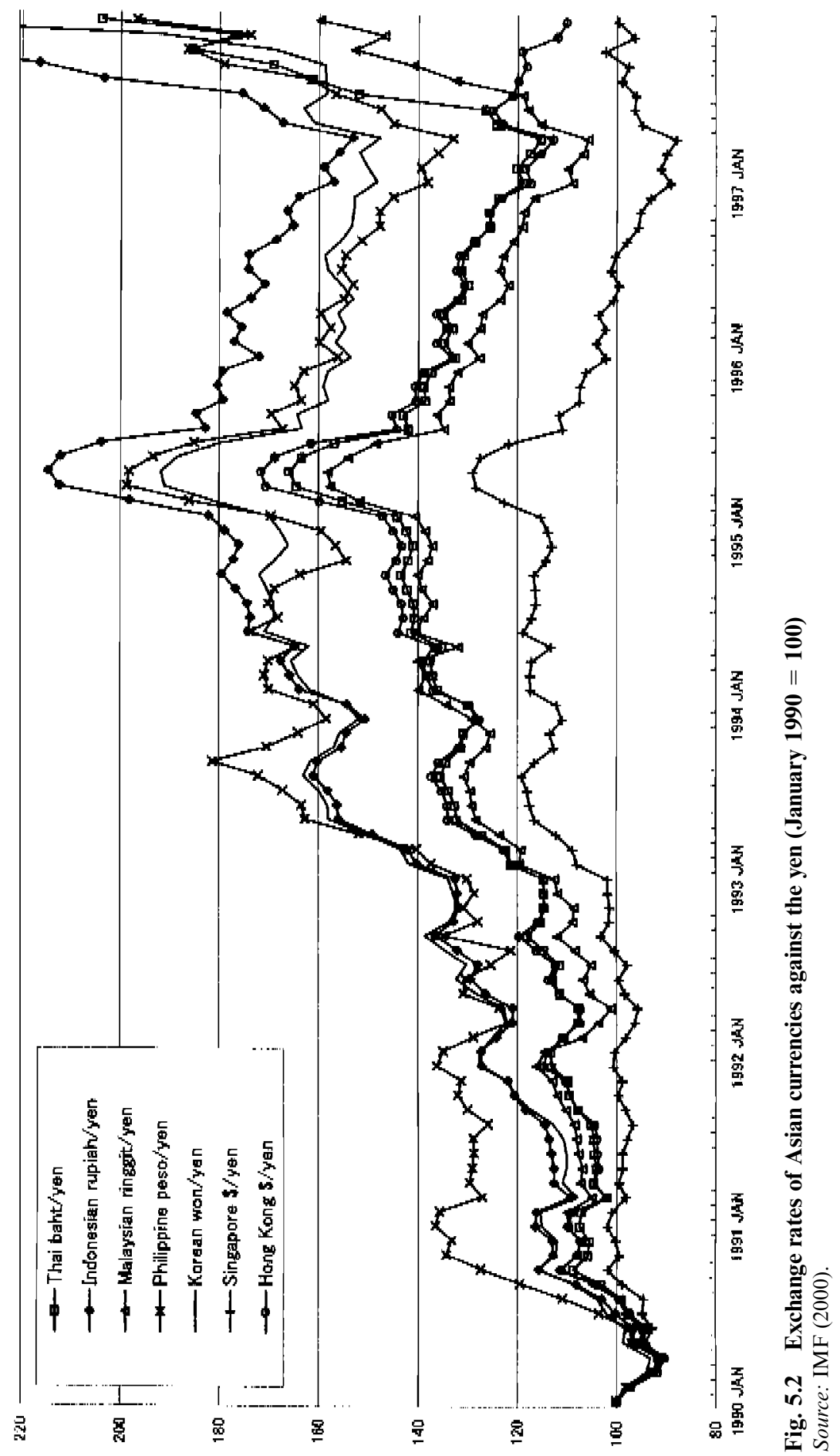


The vacillations in the exchange rates have had negative effects on the international trade competitiveness of these countries. Figure 5.3 shows movements of the real effective exchange rates of these countries. The real effective exchange rates of the Thai baht, the Malaysian ringgit, and the Indonesian rupiah fluctuated without any appreciating trends in the early 1990s. However, they began appreciating after May 1995. The Korean won was the only one to be fluctuating without any appreciating trend throughout the period 1992-97. Thus, the real effective exchange rates of the currencies except for the Korean won began appreciating since 1995. The de facto dollar peg system and the depreciation of the yen against the U.S. dollar influenced these movements in the real effective exchange rates.

In the early 1990s, depreciation of the U.S. dollar against the yen depreciated the countries' currencies against the yen under the de facto dollar peg system. Although these countries had trade deficits due to increases in imports of capital goods - which is a sign of good economic growthexports in these countries had been steadily increasing due to the depreciation of their currencies against the yen. Nevertheless, the depreciating trend of the yen against the U.S. dollar after 1995 decreased the competitiveness of these countries against Japan, and in turn, decreased growth rates of export revenues. The movements of the export growth rates of Thailand, Korea, and Indonesia are shown in figure 5.4.

It is not so important whether or not a country has trade deficits as long as its imported capital goods continue to increase its future production capacities and export revenues. ${ }^{2}$ However, if the export growth rate is decreasing at the present time and is expected to continue to decrease in the future, the present trade deficits will not be sustainable. The expectation could trigger speculative attacks against the currency even if these countries are increasing their foreign reserves.

Private capital inflows to Thailand, Indonesia, and Korea increased in the 1990s as shown in figures 5.5 to 5.7. The figures show that there was an oversurge of capital inflows to all three countries in 1995 and 1996. The oversurge of capital inflows to Thailand was mainly caused by other investments, such as international bank loans. Figure 5.6 shows that portfolio investments to Korea were larger than international bank loans in 1993 but that the opposite was true after 1994. Because private capital inflows had reached their peak in 1996, the international bank loans prevailed in the capital inflows to these Asian countries. This is the opposite of the situation in Latin American countries, where the portfolio investments prevailed in the capital inflows.

Movements in flows of international bank loans categorized by countries are shown in figures 5.8 through 5.10. In the case of Thailand, the share of Japanese banks was relatively high in 1994 and 1995. European

2. Frankel and Rose (1996) obtained a result that current account deficits are insignificant as a cause of currency crisis, as they were for the past currency crisis. 


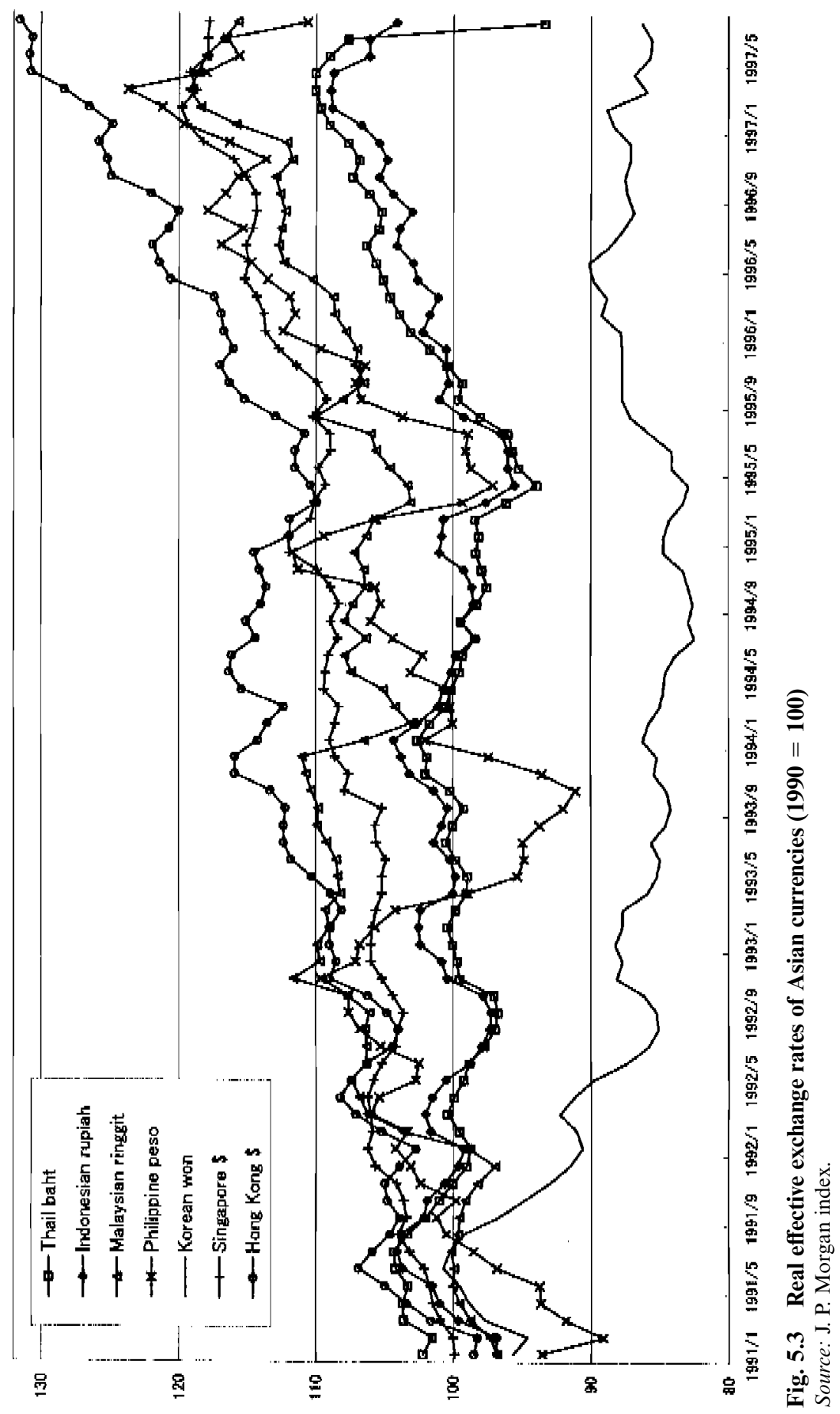




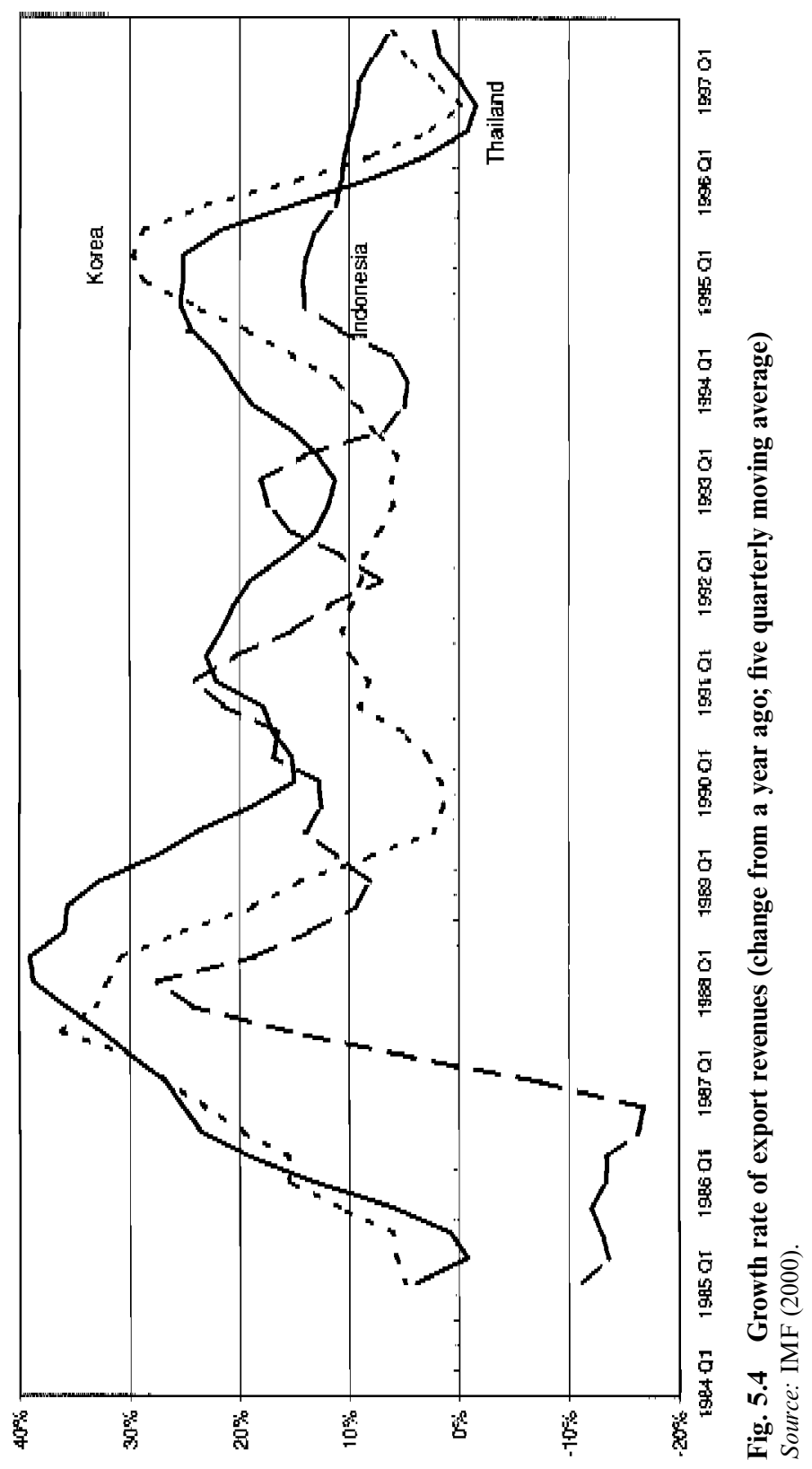




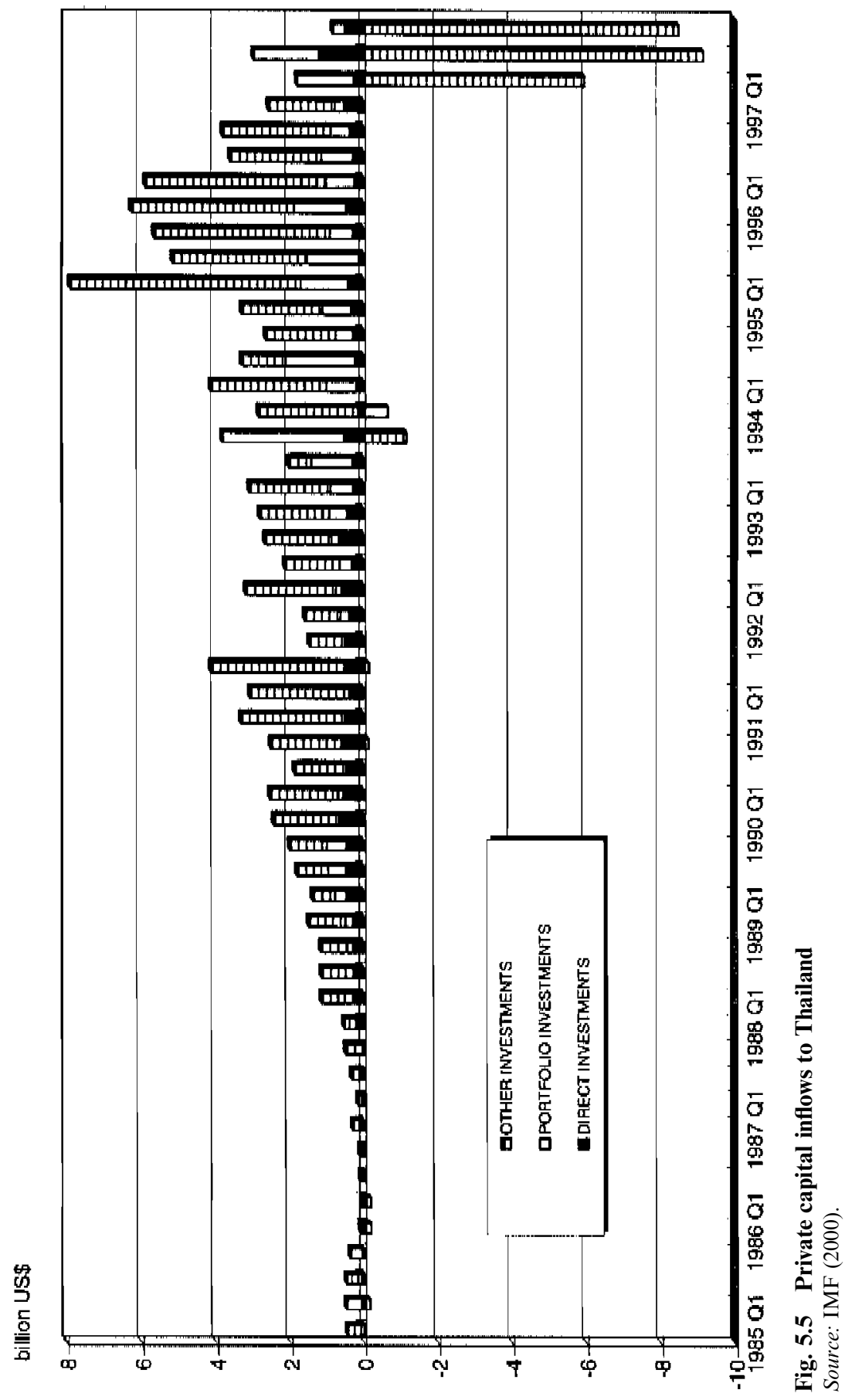




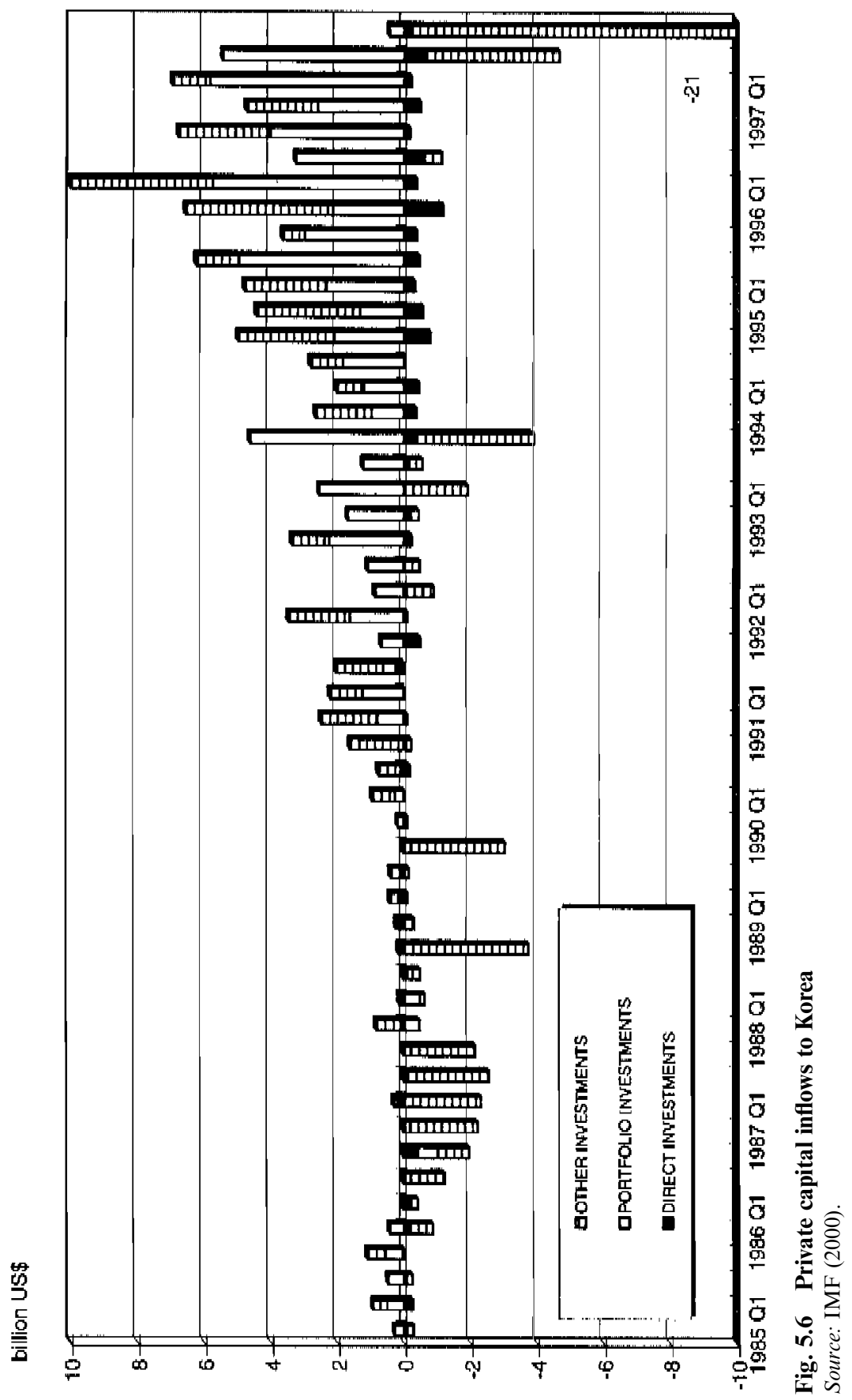




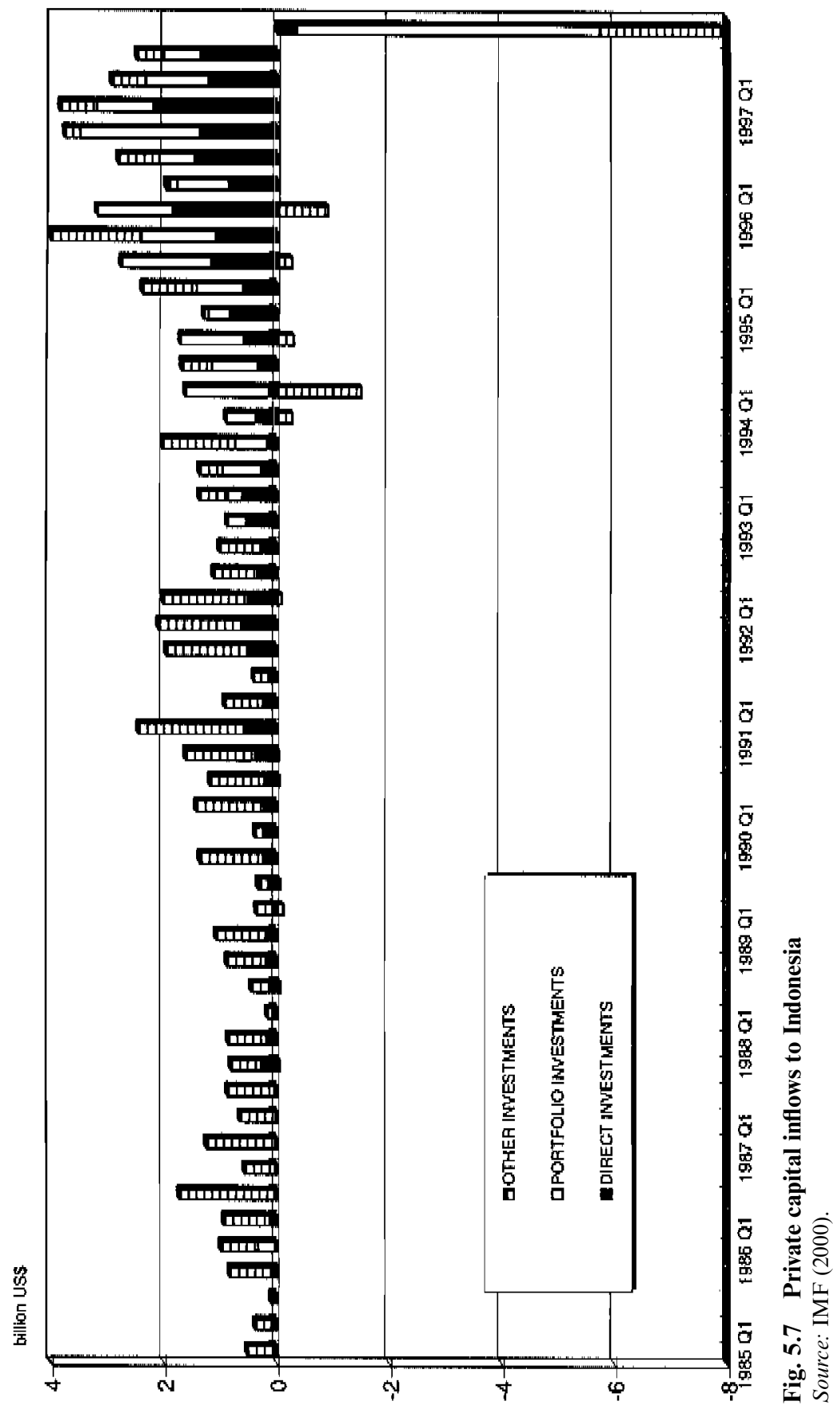




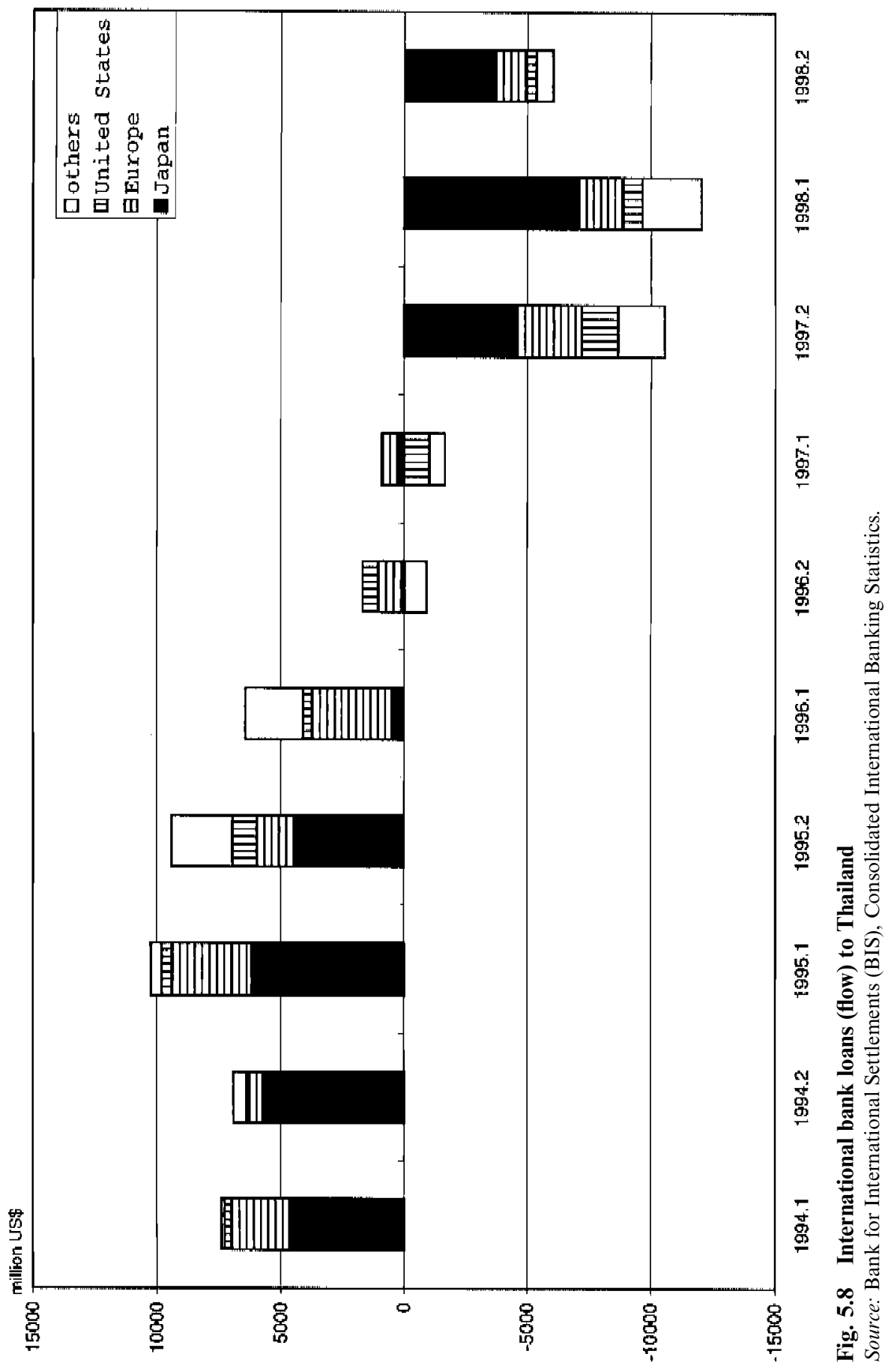




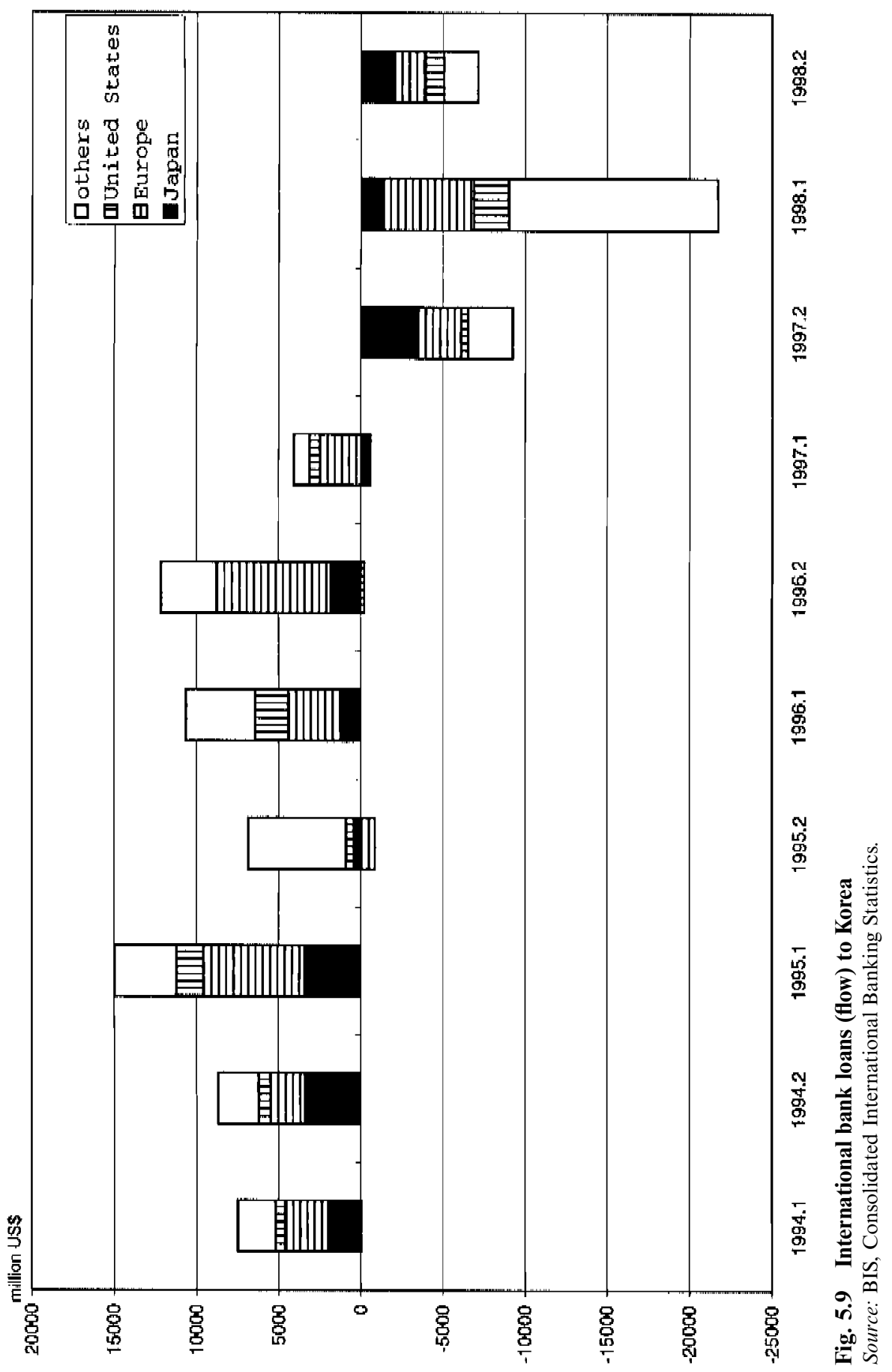




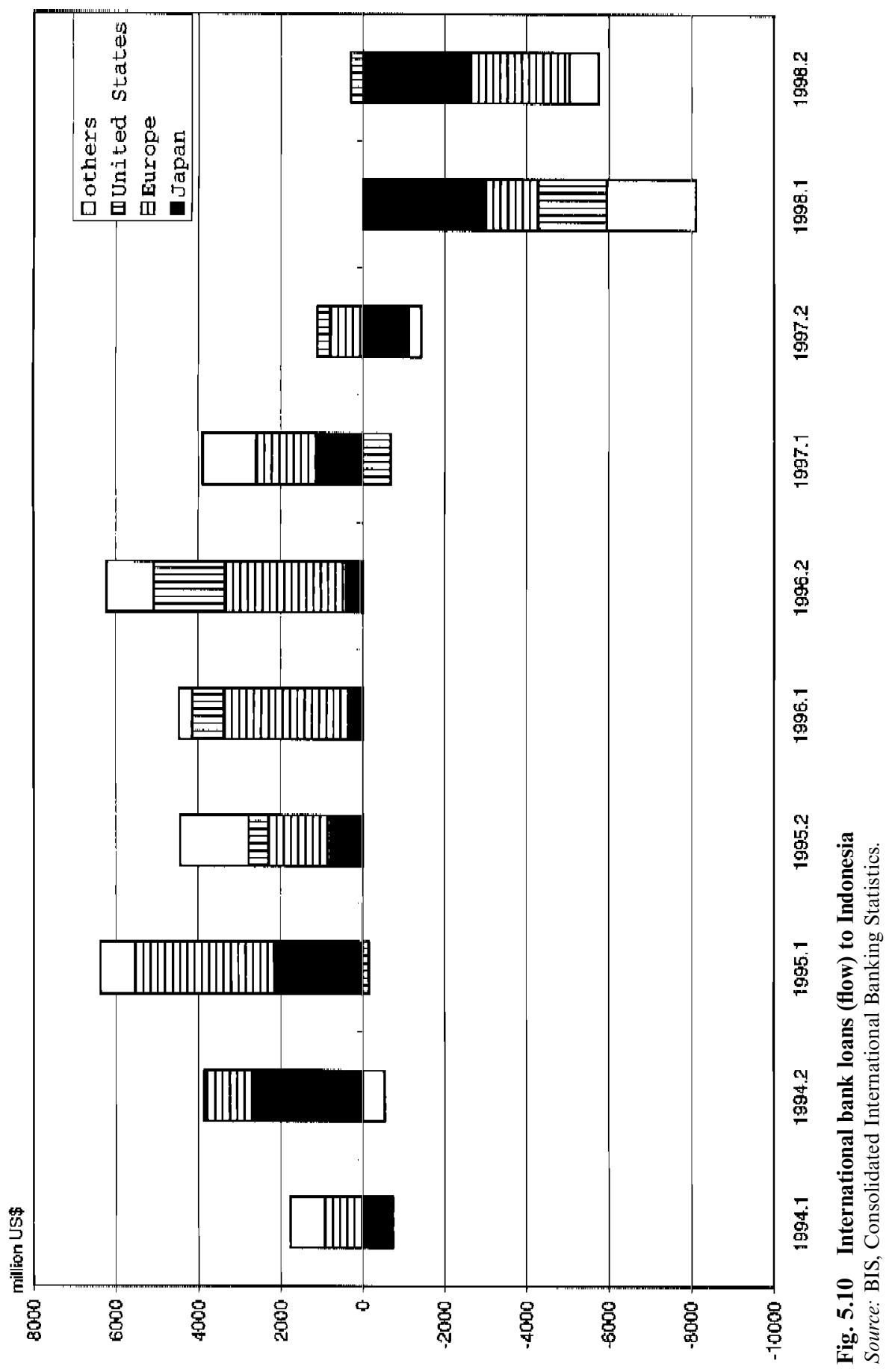




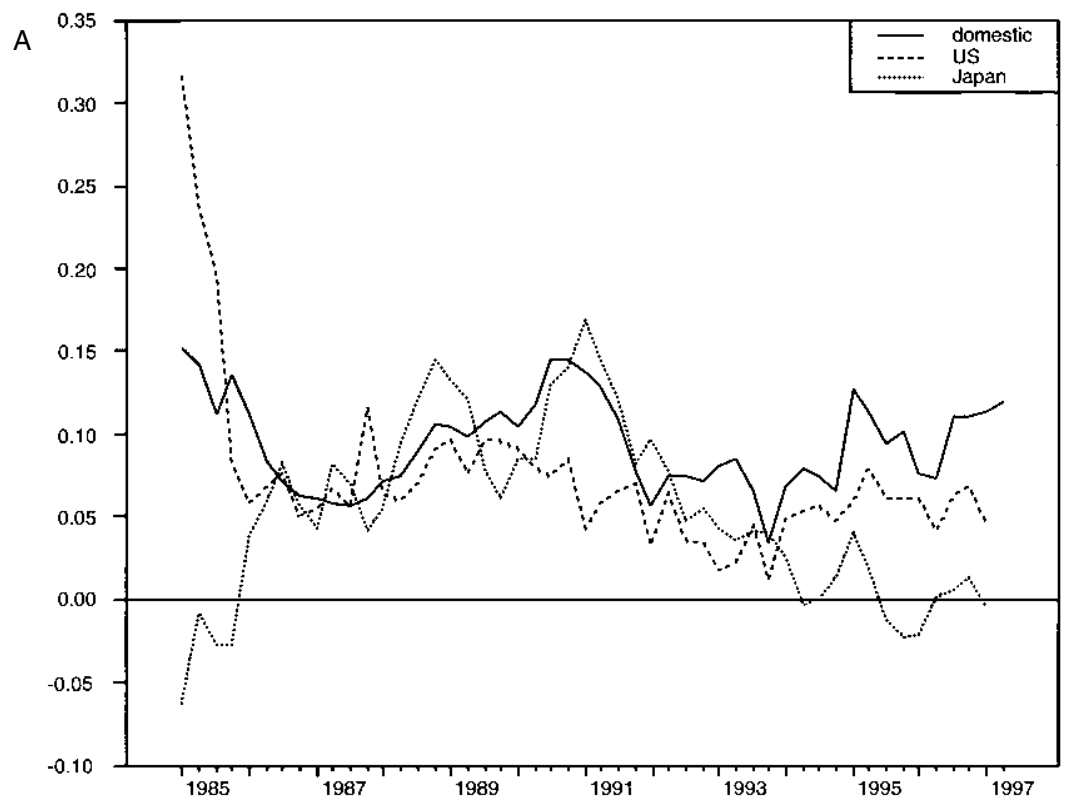

Fig. 5.11 Interest rates: $A$, Thailand; $B$, Korea; $C$, Indonesia

banks also increased their loans to Thailand in 1996. Although flows of international bank loans to Korea and Indonesia by European banks seemed to be higher than Japanese banks, Kaminsky and Reinhart (chapter 3, this volume) pointed out that Japanese banks had larger shares in stocks of international bank loans in these three countries.

The impact of both the de facto dollar peg system and depreciation or appreciation of the U.S. dollar against the yen on interest rates is examined. We calculate exchange rate adjusted foreign interest rates by adding expected depreciation rates of the domestic currency to the relevant foreign interest rate. ${ }^{3}$

Figure 5.11 shows movements of exchange rate adjusted foreign interest rates and domestic interest rates. ${ }^{4}$ The movements of the interest rates had some common characteristics. Both the U.S. and the Japanese interest rates tended to be lower than the domestic interest rates in the 1990s.

3. The expected depreciation rates of the home currency at each period are calculated by assuming that economic agents use data on rates from the last five years to forecast exchange rates as explained in the next section. Specifically, we use a time series model of the ARIMA $(1,1,1)$ process to forecast a value of the next period based on historical data of the last five years for the relevant exchange rate.

4. Values in figure 5.11 are seasonally adjusted data of the exchange rate-adjusted interest rate in terms of the U.S. dollar and the yen that are used in a regression analysis in section 5.3 . 

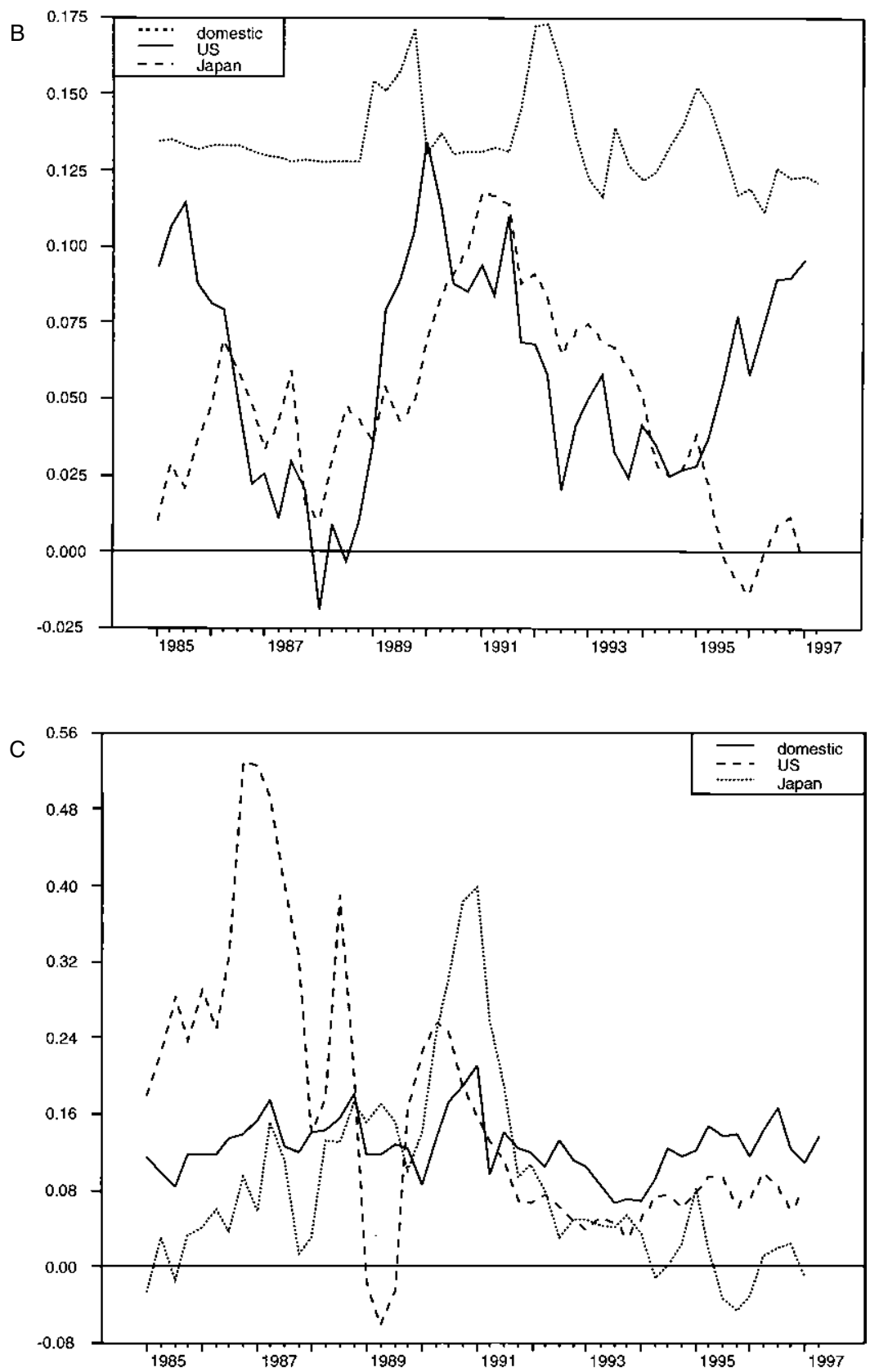

Fig. 5.11 (cont.) 
Moreover, the Japanese interest rates have been consistently lower than the U.S. interest rates since 1995.

Before turning to regression analysis of the capital inflows, let's look at the timing between the surge of capital inflows and the asset bubbles in these countries. The countries in crisis experienced asset bubbles in the 1990s during different time periods as shown in figure 5.12. Thailand and Indonesia experienced a bubble of stock prices in 1993. They had a peak of stock prices in the latter half of 1993. The stock prices in Korea also increased from 1993 through 1994. The stock prices in Thailand and Korea were kept at high levels during 1995. However, they started to drop sharply after early 1996. In Indonesia, the stock prices continued to increase until early 1997, but they also dropped sharply afterward. As shown, the bubble and the peak of stock prices preceded the surge of capital inflows in 1995 and 1996. Thus, we can conclude that no bubbles in stock prices seemed to stimulate capital inflows to these countries.

\subsection{Capital Inflows under the Dollar Peg System}

\subsubsection{A Simple Model of Capital Inflows}

We first conduct a regression analysis of capital inflows to the countries under the de facto dollar peg system in order to analyze empirically how the de facto dollar peg system influenced capital inflows to these countries. We then set up a model of capital inflows to be estimated in a regression analysis. The model consists of a capital flow equation and equations that explain some of the instrumental variables in the capital flow equation.

In many developing countries including those in East Asia, monetary authorities impose measures to control international capital flows. Therefore, capital flows are caused by partial adjustments of capital asset stocks to changing optimal levels. According to a portfolio-balance approach, the risk-averse investors should attempt to hold optimal portfolio balances of foreign assets denominated in terms of foreign currencies relative to domestic assets denominated in terms of the home currency. The optimal portfolio balances are determined by both relative expected return rates and foreign exchange risks.

Thus, capital flows are influenced by factors such as domestic interest rate, exchange rate-adjusted foreign interest rates, and foreign exchange risks. Positive exchange rate-adjusted interest rate differentials stimulate capital inflows to these countries from the viewpoint of foreign lenders and domestic borrowers. Signs of coefficients of the domestic interest rates are expected to be positive, and exchange rate-adjusted foreign interest rates to be negative. Coefficients of foreign exchange risks are also expected to be negative. Thus, foreign exchange risks depress economic agents' foreign lending and borrowing if they are risk averse. 


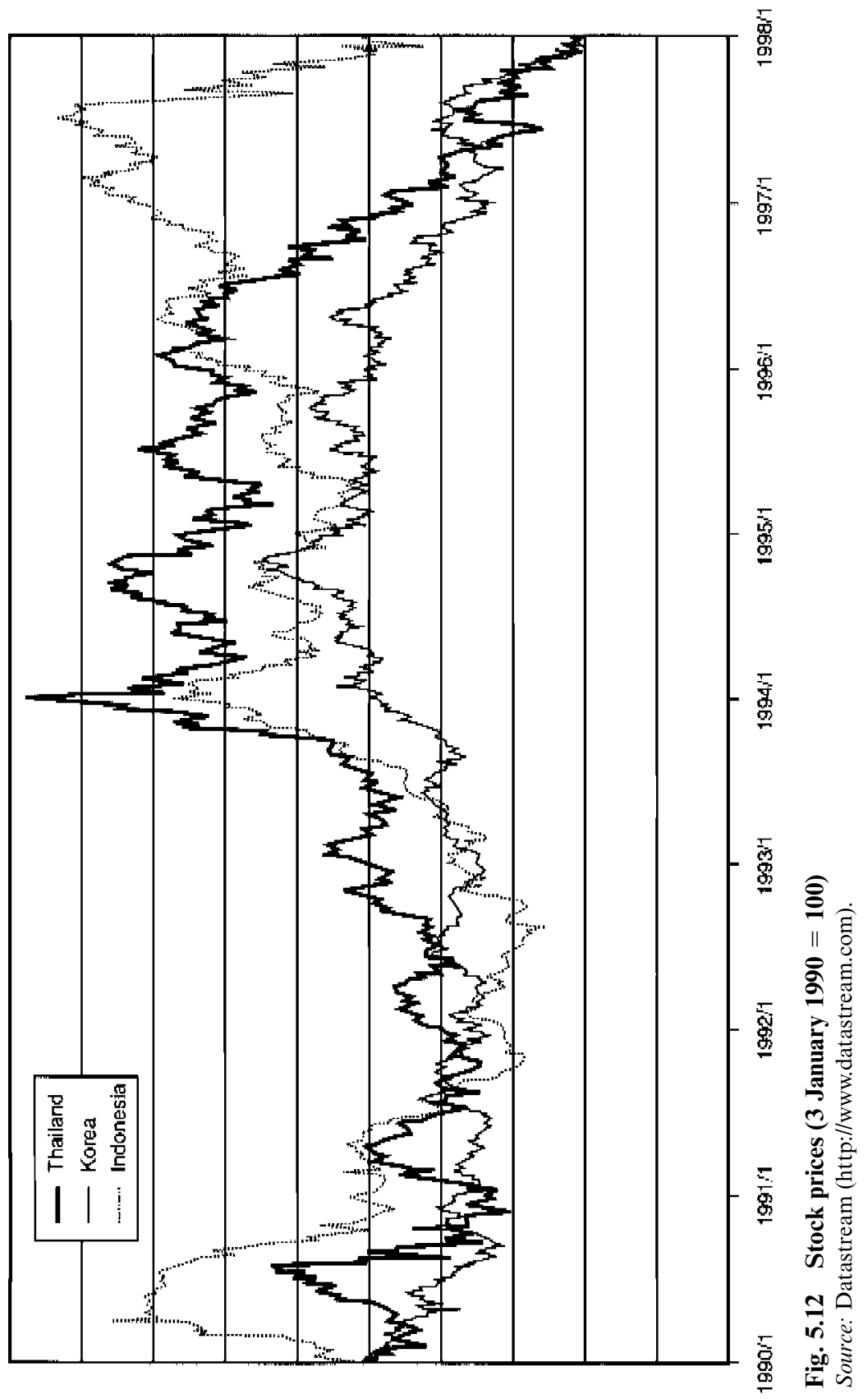


We also take into account the possible effects that a rate of change in domestic stock prices has on capital flows. Increases in domestic stock prices also stimulate foreign investors to invest in domestic stocks. Also, they might encourage both domestic borrowers to borrow from abroad and foreign lenders to lend to the domestic economy. Thus, coefficients on the variables should be positive.

Moreover, a higher export growth rate might give domestic borrowers easier access to international capital because they are regarded to have a higher capacity to repay their debt. Economies with higher economic growth should have more sustainable levels of foreign debts according to intertemporal macroeconomic models. In small developing countries, economic growth tends to depend a lot on export growth. Thus, a higher export growth rate might have positive effects on capital inflows.

We regress capital flows on the explanatory variables with a time lag to take into account the causality between the explanatory variables and the capital flows. A ratio of capital flow to nominal GDP is used in order to eliminate an increasing trend in capital flows. A capital flow equation is formalized below:

$$
\begin{aligned}
\mathrm{cf}_{t}= & a_{1}+a_{2} i_{t-1}+a_{3} d i_{t-1}+a_{4} y i_{t-1}+a_{5} d \text { risk }_{t-1}+a_{6} y \text { risk }_{t-1} \\
& +a_{7} \Delta \log X_{t-1}+a_{8} \pi_{t-1}^{\text {stock }}+\varepsilon_{t} \\
d i_{t} \equiv & i_{t}^{\text {usd }}+\left\{\log \left[E_{t}\left(s_{t+1}^{\mathrm{hc} / \text { usd }}\right)\right]-\log \left(s_{t}^{\mathrm{h} / \text { usd }}\right)\right\} \\
y i_{t} \equiv & i_{t}^{\text {yen }}+\left\{\log \left[E_{t}\left(s_{t+1}^{\mathrm{hc} / \mathrm{yen}}\right)\right]-\log \left(s_{t}^{\mathrm{hc} / \mathrm{yen}}\right)\right\},
\end{aligned}
$$

where $\mathrm{cf}$ is the ratio of capital flows to nominal GDP, $i$ is the domestic interest rate, $d i$ is the exchange rate-adjusted U.S. interest rate, $y i$ is the exchange rate-adjusted Japanese interest rate, $d$ risk is the foreign exchange risk of exchange rate of domestic currency in terms of the U.S. dollar, yrisk is the foreign exchange risk of exchange rate of domestic currency in terms of the yen, $\Delta \log X$ is the export growth rate, $\pi^{\text {stock }}$ is the rate of change in domestic stock prices, $\varepsilon$ is the error term, $i^{\text {usd }}$ is the U.S. dollardenominated interest rate, $i^{\text {yen }}$ is the yen-denominated interest rate, $s^{\text {hc/usd }}$ is the exchange rate of domestic currency in terms of the U.S. dollar, $s^{\text {hc/yen }}$ is the exchange rate of domestic currency in terms of the yen, and $E$ is the expectation operator.

We regard the domestic interest rate, export growth rate, and rate of change in stock prices to be the explanatory variables in the capital flow equation (1). We also assume that the variables are endogenous and influenced by exogenous variables.

A domestic interest rate is influenced by the above determinants of capital flows in a small economy with international capital mobility. 


$$
i_{t}=b_{1}+b_{2} d i_{t}+b_{3} y i_{t}+b_{4} d \text { risk }_{t}+b_{5} y \text { risk }_{t}+\varepsilon_{t}
$$

Interest rate arbitrage tend to make domestic interest rates move with foreign interest rates in the same direction. Under perfect capital mobility, coefficients of exchange rate-adjusted foreign interest rates would be one. However, it is not necessarily true under imperfect capital mobility. Foreign exchange risks tend to make foreign lenders prefer domestic currencydenominated assets to other currency-denominated assets. In contrast, they tend to make domestic borrowers prefer domestic currency-denominated liabilities to other currency-denominated liabilities. The preferences of both foreign lenders and domestic borrowers make the domestic interest rates of the crisis countries higher than the foreign interest rates by a risk premium. Thus, coefficients of the foreign interest rates and foreign exchange risks are expected to be positive.

Exports are regarded as a function of real exchange rates and foreign incomes. Export growth rate is influenced by the depreciation rate of domestic currency against the U.S. dollar and the yen, domestic inflation rate, foreign inflation rate, and growth rate of foreign GDP. It is expected that coefficients of the depreciation rate of domestic currency and the foreign inflation rate will be negative while those of domestic inflation rates and growth rates of foreign GDP will be positive:

$$
\begin{aligned}
\Delta \log X_{t}= & c_{1}+c_{2} \Delta \log s_{t-1}^{\mathrm{hc} / \text { usd }}+c_{3} \Delta \log s_{t-1}^{\mathrm{hc} / \text { yen }}+c_{4} \pi_{t-1}+c_{5} \pi_{t-1}^{*} \\
& +c_{6} \Delta \log \mathrm{GDP}_{t}^{*}+\varepsilon_{t}
\end{aligned}
$$

where $\pi$ is the domestic inflation rate, $\pi^{*}$ is the foreign inflation rate, and $\Delta \log$ GDP* is the growth rate of foreign GDP.

In addition, the domestic inflation rate is influenced by changes in exchange rates and foreign inflation rates through a pass-through effect. It is not necessary that coefficients on depreciation rates of domestic currency and foreign inflation rates will be one if there is imperfect pass-through. ${ }^{5}$

$$
\pi_{t}=d_{1}+d_{2} \Delta \log s_{t-1}^{\mathrm{hc} / \text { usd }}+d_{3} \Delta \log s_{t-1}^{\mathrm{h} / \mathrm{yen}}+d_{4} \pi_{t-1}^{*}+\varepsilon_{t}
$$

Capital inflows might have stimulated domestic investors to invest in domestic stocks. As a result, domestic stock prices might have increased. However, stock prices would not have been influenced if the monetary authorities sterilized increases in foreign reserves. We formulate the following stock price equation to take into account the effect on stock prices.

$$
\pi_{t}^{\text {stock }}=e_{1}+e_{2} \mathrm{cf}_{t}+\varepsilon_{t}
$$

5. Krugman (1987) and Marston (1990) explained that imperfect pass-through effects were caused by exporting firms' pricing to market. 


\subsubsection{An Analytical Method and Data}

At first, we use an instrumental variable method to estimate all of the five equations. In our case, endogenous variables are the domestic interest rate, export growth rate, domestic inflation rate, and rate of change in stock prices. Economic variables in the foreign countries are exogenous under the assumption of a small open economy. We further assume that the monetary authorities can intervene in foreign exchange markets to control exchange rates. Accordingly, we assume that not only actual and expected depreciation rates of domestic currency, but foreign exchange risks are also controlled by the monetary authorities although both the expected depreciation rates and foreign exchange risks are perceived by investors and might be forward-looking variables. Both are regarded as exogenous policy variables.

Next, after we check the signs of coefficients on export growth rate and rate of change in stock prices in the capital flow equations, we drop variables whose coefficients have an incorrect sign. The instrumental variable method is again used to estimate all of the equations for the selected instrumental variables. Interest rates and foreign exchange risks are kept as explanatory variables in the second round of estimation because we want to focus on the basic determinant variables of capital flows.

It is difficult but nevertheless important to generate a time series of expected exchange rates for countries where data on expected exchange rates is unavailable. Here, we assume that both foreign lenders and domestic borrowers act on the basis of expectations, and that foreign exchange risks are calculated by using historical data on exchange rates, although we cannot forecast the effects that expected future events such as a peso problem have on exchange rates. Data of the past five years from each period are used to forecast exchange rates in the next period according to a time series model (autoregressive integrated moving-average [ARIMA] 1,1,1). The forecasted values are used as the expected exchange rate.

We use the forecasted values of exchange rates to calculate foreign exchange risks. We further assume that both foreign lenders and domestic borrowers regard standard deviations of actual exchange rates from the forecasted values as foreign exchange risks. ${ }^{6}$ Figure 5.13 shows movements of foreign exchange risks in Thailand, Indonesia, and Korea. The foreign exchange risks against the U.S. dollar were lower than those against the yen over the analyzed period in all of these countries. All foreign exchange

6. We have another option to calculate foreign exchange risks. The foreign exchange risks can be assumed to be standard errors of the time series model, i.e., deviations of actual exchange rates from the estimated values. However, standard errors are almost unchanged once a large devaluation of exchange rate occurs. We do not choose this calculation because it is not natural for foreign exchange risks to remain unchanged for a period of time after the large devaluation. 


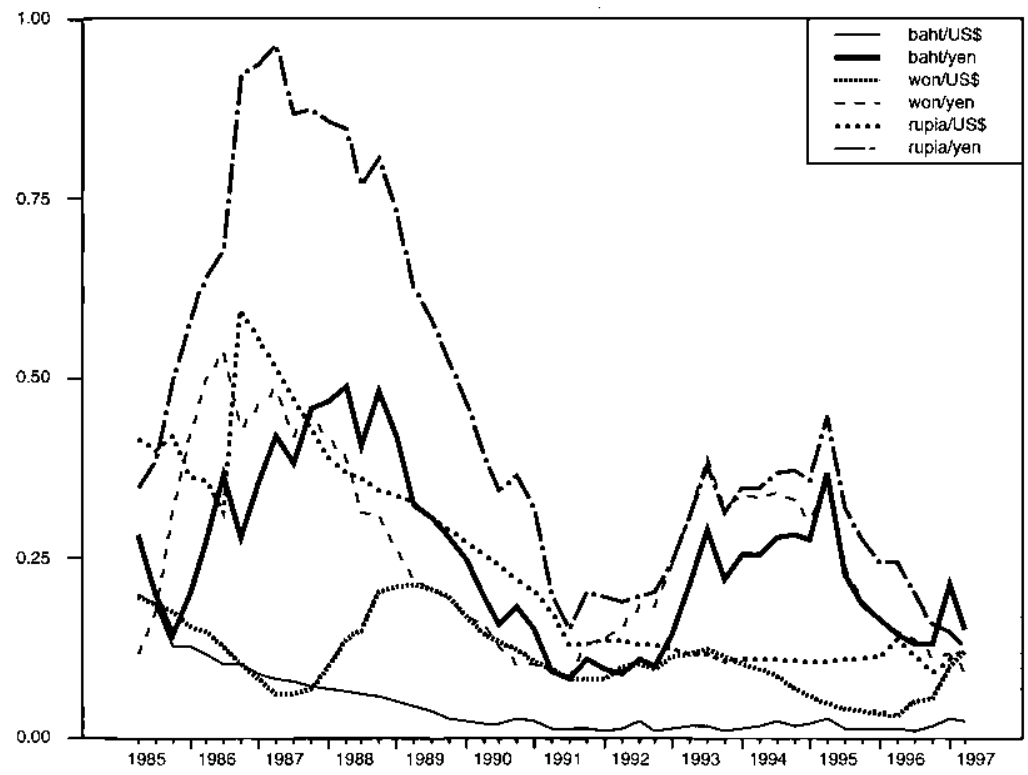

Fig. 5.13 Foreign exchange risks (deviations from a forecast value)

risks were lower during the 1990s than during the 1980s. The foreign exchange risks against the yen jumped in 1993 and kept increasing from 1993 to 1995 in all three countries.

Quarterly data are used in all of the regression analyses due to data constraints. Monthly data on the exchange rates are used in order to secure a sample size for making an autoregression of the exchange rates according to the ARIMA model. Monthly data are then converted to quarterly data by simply averaging the data over a three-month period. We chose to analyze the period between the Plaza Agreements of September 1985 and the Thai baht crisis of July 1997. Accordingly, the period lasts from the first quarter of 1986 to the first quarter of 1997 for all three countries.

"Other investments" in the financial account of the balance of payments is used as the major proxy on capital inflows, because international bank loans prevail in capital inflows to these countries. "Portfolio and other investments" is also present in Thailand and Korea. Data on portfolio investments are not available due to missing values in the data.

We add dummy variables that show a representative deregulation of international capital transactions that are statistically significant in explaining variables when estimating the capital flow equations. In Thailand, the Bangkok International Banking Facility opened in March 1993. In Indonesia, regulations on foreign borrowings of financial institutions were removed in March 1989. Korea also had regulations on foreign borrowings 
of financial institution removed in 1989. Accordingly, a dummy variable is added from the second quarter of 1993 for Thailand, from the first quarter of 1989 for Korea, and from the second quarter of 1989 for Indonesia.

We select the United States and Japan as foreign influences for these three countries because they trade heavily with the United States and Japan. As for both the foreign inflation rate and the growth rate of foreign GDP, simple averages of the U.S. and Japanese data are calculated.

As for data on interest rates, we use money market interest rates such as the call rates for Thailand and Indonesia because deposit interest rates and loan interest rates are kept unchanged. A three-month commercial paper $(\mathrm{CP})$ interest rate is used for Korea, and a three-month London Interbank Offered Rate (LIBOR) is used for both Japan and the United States. As for inflation rates, wholesale price indexes are used for Thailand, Indonesia, and Japan, whereas producer price indexes are used for Korea and United States.

All data except for stock prices are available from the International Financial Statistics IMF CD-ROM. Data on stock price can be found in Datastream (http://www.datastream.com). When conducting the regression analysis, seasonal adjustments were made for the data that require it. Regressions are estimated by correcting for first-order serially correlated errors when necessary.

\subsubsection{Results of the Regression Analysis}

\section{Capital Flow Equations}

We use equation (1) to regress all capital inflows on interest rates, foreign exchange risks, export growth rate, rates of changes in stock prices, and a deregulation dummy for each country.

As for the other investments of Thailand, coefficients on both the domestic interest rate and foreign exchange risk against the U.S. dollar are statistically significant and in the correct signs, as shown in equation (1), specification (a) (henceforth equation [1a]; likewise equations [1b]-[1k], etc.). Coefficients on the U.S. interest rate, foreign exchange risk against the yen, and rate of change in stock prices are also in the correct signs, although they are statistically insignificant. The coefficient on the export growth rate is in the wrong sign, and the deregulation dummy is statistically insignificant. As a result, both the export growth rate and deregulation dummy are dropped from the capital flow equation in the next round of estimation.

In the second regression, we obtain the results shown in equation (1b) in table 5.2. The results are almost the same as those of equation (1a). $P$-value of both the domestic interest rate and the foreign exchange risk against the U.S. dollar are lower than those in equation (1a). It is noteworthy that a responsiveness of capital flows to the foreign exchange risk 


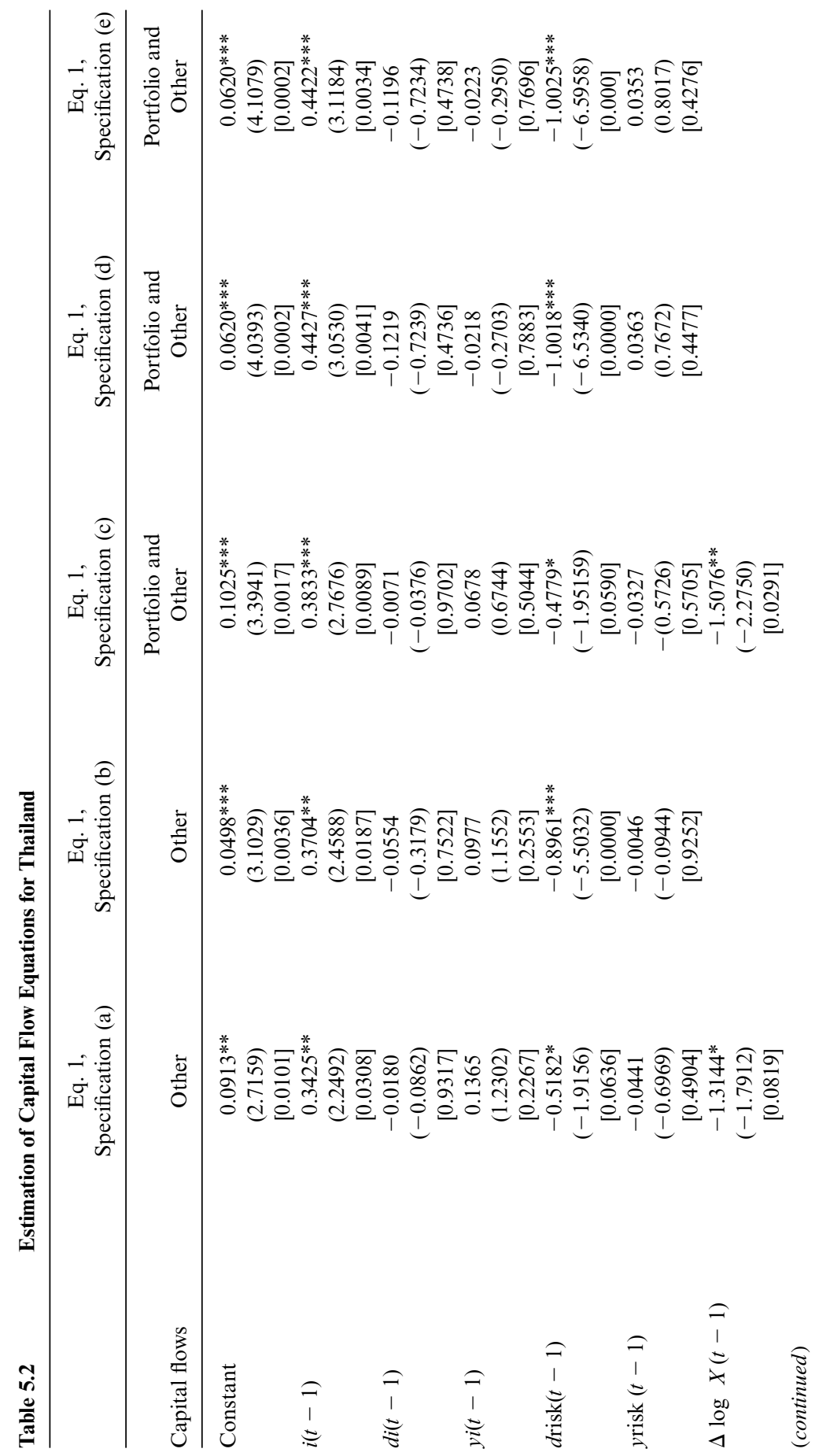




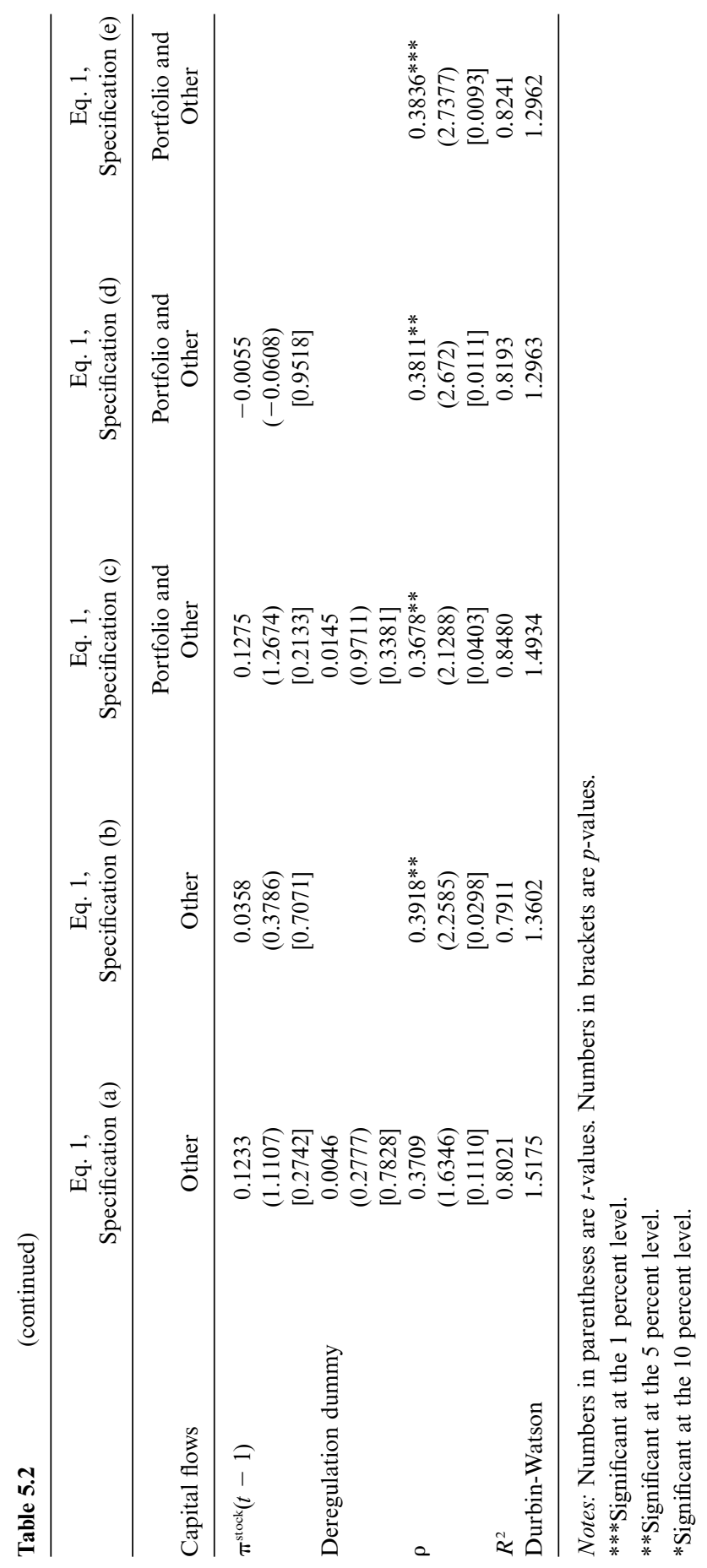


against the U.S. dollar is much larger compared to the foreign exchange risk against the yen. It is expected that this asymmetry will induce capital inflows to decrease under the currency basket peg system where the standard deviation for the U.S. dollar increases and the standard deviation for the yen decreases.

As for the "portfolio and other investments" of Thailand, a result similar to "other investments" is obtained. Equation (1c) in table 5.2 shows that coefficients on both the domestic interest rate and the foreign exchange risk against the U.S. dollar are statistically significant and of the correct signs. The coefficient on the export growth rate is significant but of the wrong sign, while the deregulation dummy is statistically insignificant.

Equation (1d) documents the results of regressing "portfolio and other investments" without the export growth rate and deregulation dummy. The coefficient of the rate of change in stock prices becomes negative. This variable is dropped from the capital flow equation because its coefficient has an incorrect sign, and we obtain new results shown in equation (1e). Coefficients on both the domestic interest rate and the foreign exchange risk against the U.S. dollar are statistically significant and of the correct sign.

As for both the "other investments" and the "portfolio and other investments" of Korea, coefficients on the foreign exchange risk against the U.S. dollar are statistically significant and negative as expected. The deregulation dummy is statistically significant and positive, and the coefficients on the export growth rate and the rate of change in stock prices are of the wrong sign.

As shown in table 5.3, we obtain capital flow equations (1g) and (1i) when we drop the export growth rate and the rate of change in stock prices from equations (1f) and (1h). Coefficients on the foreign exchange risk against the U.S. dollar are negative while their $p$-values are lower than those in equation (1f) and (1g). Coefficients on the domestic interest rates turn positive although the variable is statistically insignificant. A responsiveness of the capital flows to the foreign exchange risk against the U.S. dollar is greater than that against the yen.

In the case of Indonesia, a satisfactory capital flow equation cannot be obtained - especially, the variable of the export growth rate is statistically significant but of the wrong sign. A capital flow equation is reestimated after dropping both the export growth rate and the deregulation dummy in equation (1j), but the result is the same.

The rate of change in stock price variables is statistically insignificant regardless of the sign in the capital flows equation for all three countries. It implies that the rate of change in stock prices did not influence the capital inflows to the countries. The result of the regression analysis is consistent with our hypothesis that stock price bubbles did not stimulate capital inflows to the countries. 


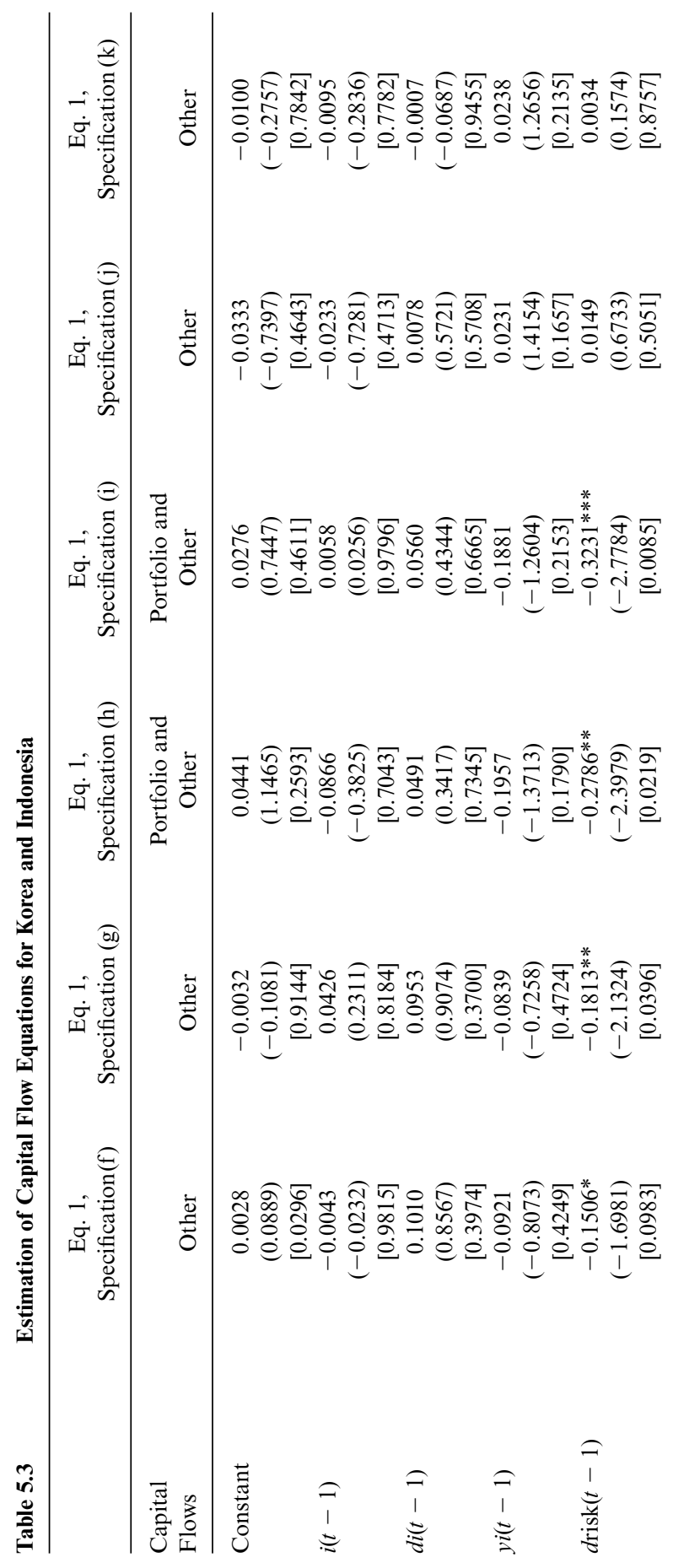




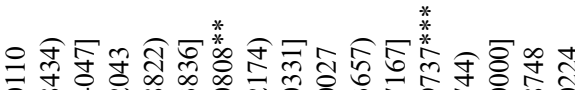

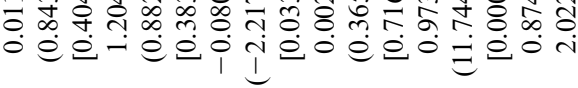

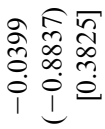

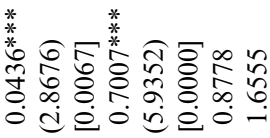

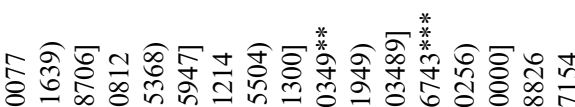

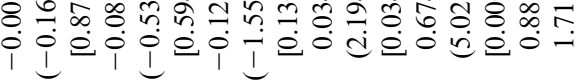

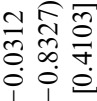

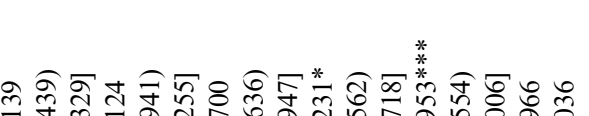
उ.

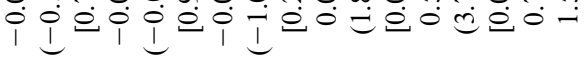

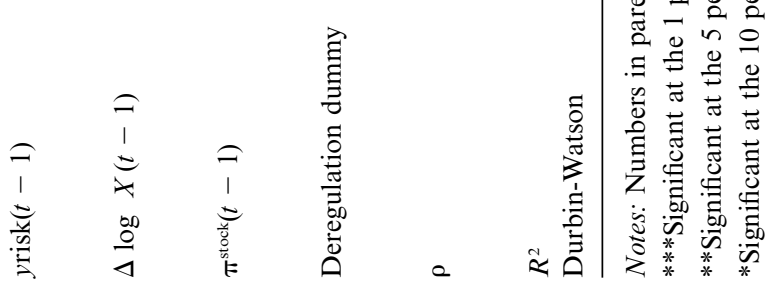




\section{Other Estimation Equations}

Results of estimating the equations relevant to the selected instrumental variables are shown in table 5.4. The domestic interest rate and the rate of change in stock prices are selected as instrumental variables in the case of the "other investments" for Thailand, and only the domestic interest rate is selected as an instrumental variable in the case of the "portfolio and other investments" for Thailand. In equation (2a) with domestic interest rate as the dependent variable, both variables of exchange rate-adjusted foreign interest rates are statistically significant and have a positive coefficient, although they are not significantly one. Equation (5a) with the rate of change in stock prices as the dependent variable has no statistically significant variables, indicating that no external factors influenced the stock prices.

In the case of Korea, only the domestic interest rate is selected as an instrumental variable. In equation ( $2 b)$, the exchange rate-adjusted Japanese interest rate variable is statistically significant. The exchange rateadjusted U.S. interest rates and the foreign exchange risk against the yen are also relatively significant (with $p$-value of approximately 0.11 ).

Domestic interest rate, export growth rate, and domestic inflation rate are selected as instrumental variables in the case of Indonesia. The exchange rate of the Indonesian rupiah in terms of the U.S. dollar is statistically significant in both equation (3a), with export growth rate as the dependent variable, and (4a), with domestic inflation rate as the dependent variable. None of the three selected explaining variables have an effect on the change of domestic interest rate, as shown in equation (2c).

\subsection{Capital Inflows under a Basket Peg System}

\subsubsection{A Simulation Method}

In this section, a simulation analysis of capital inflows is used to analyze how a currency basket peg system would have influenced the capital inflows. We then compare the capital inflows under the actual de facto dollar peg system with results of the simulation. A currency basket peg system means that the monetary authorities increase the weight on the yen and decrease the weight on the U.S. dollar in the currency basket to which the domestic currency is pegged. A currency basket peg system is likely to change the fluctuations in exchange rates against the U.S. dollar and the yen.

We assume that coefficients on the explanatory variables in the regression equations estimated in the previous section are unchanged even if the monetary authorities change their exchange rate policy. ${ }^{7}$ If the currency

7. The Lucas critique tells us that the change in the exchange rate policy might change the coefficients in the estimated equations. 


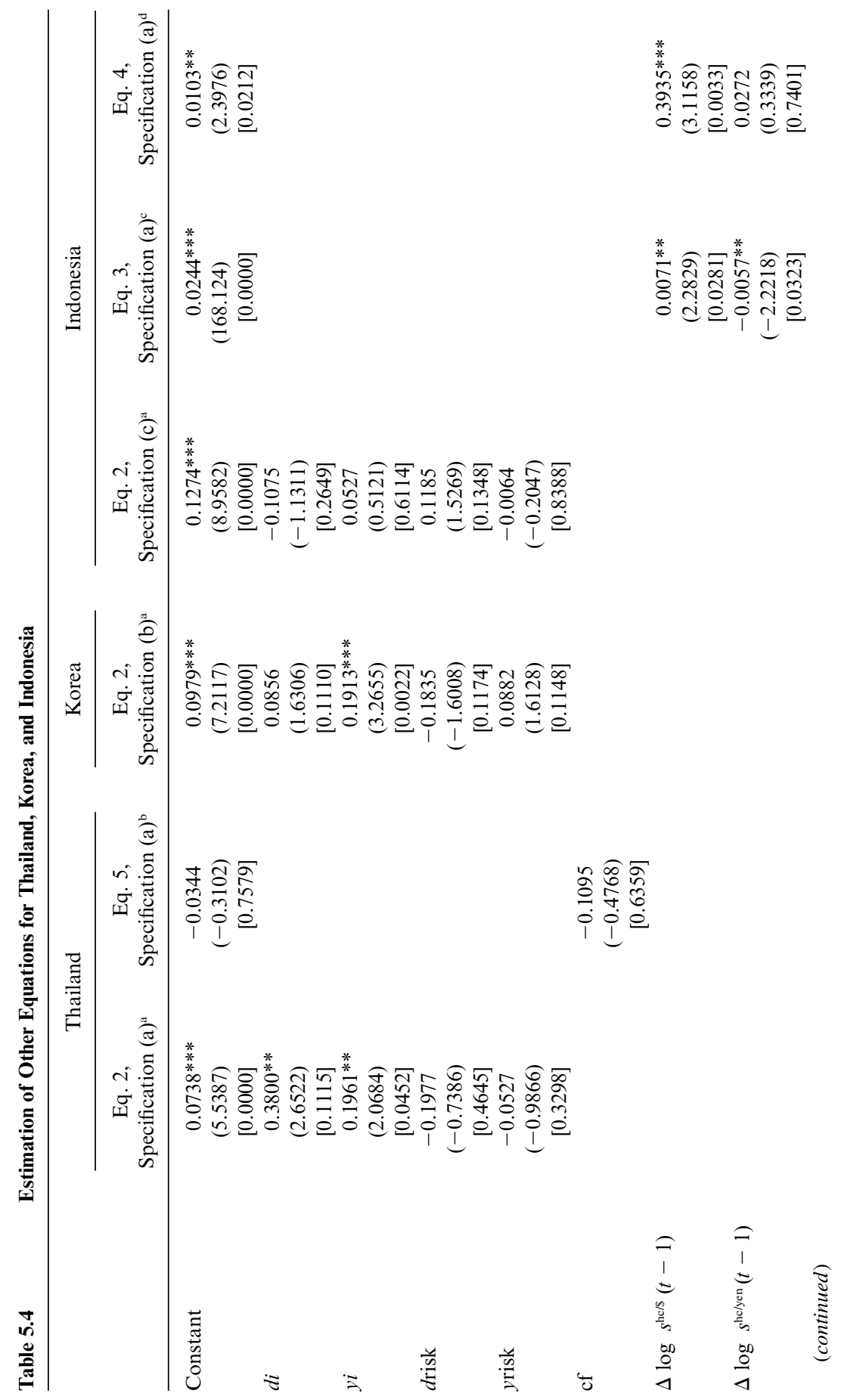




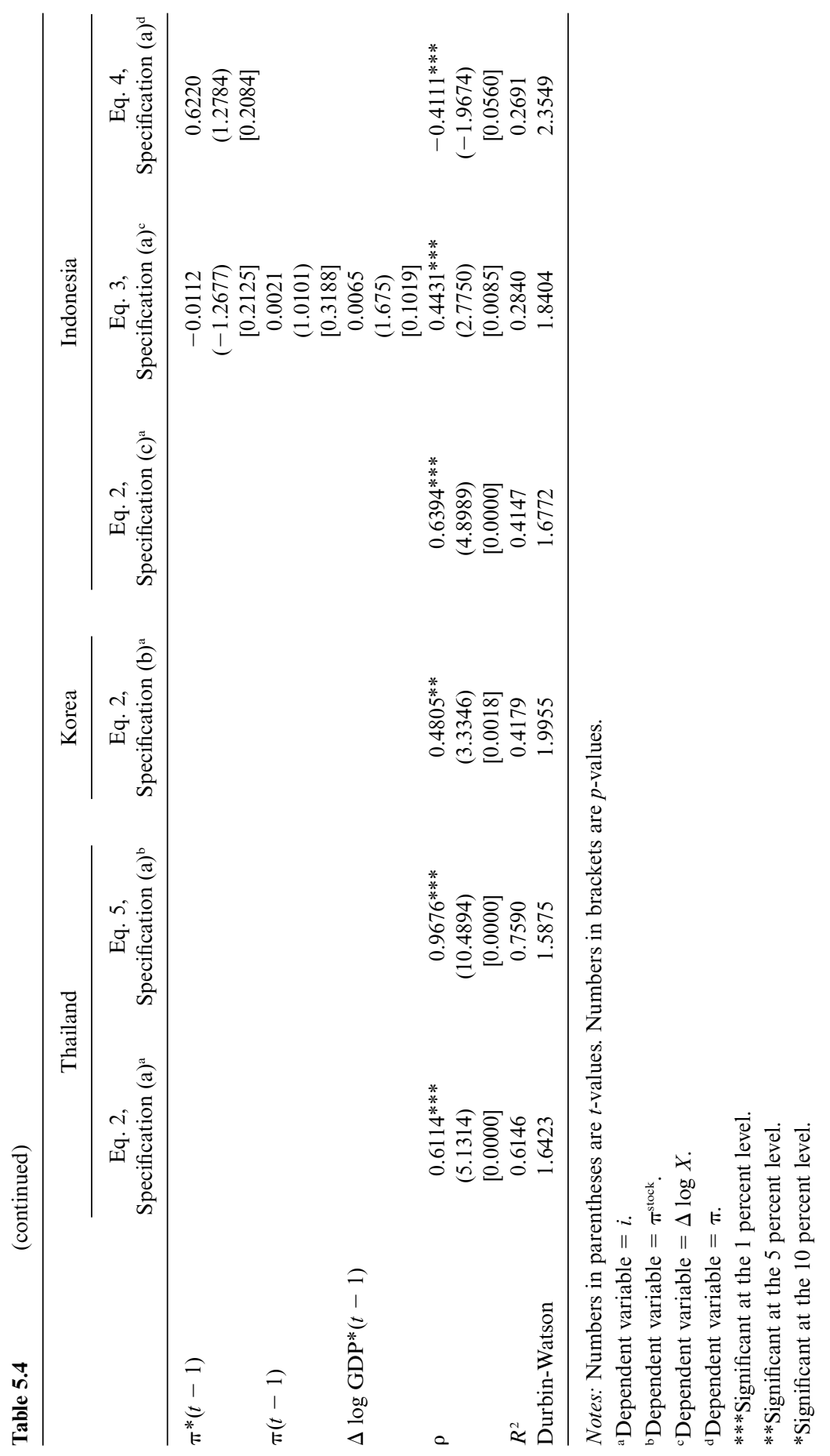


basket peg system influences fluctuation in exchange rates, it will certainly change actual and expected change in exchange rates and the standard deviations of exchange rates (foreign exchange risk) from the forecast. The currency basket peg system should have a direct impact on exchange rateadjusted foreign interest rates via the expected changes in exchange rates. Thus, it has direct effects on capital inflows via the foreign interest rates and the foreign exchange risk variables. Since we use an instrumental variable method to estimate the regression equations, we can analyze not only the direct effects but also the indirect effects that minor instrumental variables, such as the domestic interest rate and export growth rate, have on capital inflows.

If the monetary authorities adopted the currency basket peg system instead of the de facto dollar peg system, the weight on the U.S. dollar in a currency basket would be lowered, and the weight on the yen would be increased. Consequently, the exchange rate of the domestic currency against the U.S. dollar would fluctuate more, and the exchange rate of the domestic currency against the yen would fluctuate less.

Assuming that the monetary authorities stabilize the exchange rate of domestic currency against a currency basket consisting of only the U.S. dollar and the yen, we come up with the following equation:

$$
0=\omega \Delta s^{\text {hc/usd }}+(1-\omega) \Delta s^{\text {hc/yen }}
$$

where $\Delta s^{\text {hc/usd }}$ is the rate of change in the exchange rate of the domestic currency against the U.S. dollar, $\Delta s^{\text {hd/yen }}$ is the rate of change in the exchange rate of the domestic currency against the yen, and $\omega$ is a weight on the U.S. dollar in a currency basket.

From equation (6), we can obtain the following equation:

$$
\frac{1-\omega}{\omega}=-\frac{\Delta s^{\mathrm{hc} / \mathrm{usd}}}{\Delta s^{\mathrm{hc} / \mathrm{yen}}} \text {. }
$$

Supposing that the actual weight on the U.S. dollar is $0.8(\omega=0.8)$, the ratio of the fluctuations in the exchange rates of the domestic currency against the U.S. dollar to the exchange rate of domestic currency against the yen would be 1:4. If the monetary authorities decreased the weight on the U.S. dollar in a currency basket to 0.5 , the ratio of fluctuations in exchange rate would be 1 .

Assuming that the changes in exchange rate fluctuations are equally divided into both the changes in exchange rate fluctuations against the U.S. dollar and against the yen, we take a square root of the change in the fluctuation ratio to calculate the changes in exchange rate fluctuations. Under the currency basket peg system, fluctuations of the exchange rate of the domestic currency against the U.S. dollar would be doubled, whereas fluctuations of the exchange rate against the yen would be halved. 
In addition, we assume that the foreign exchange risks, which are supposed to be deviations from the forecast value, would be changed in the same direction as fluctuation of the exchange rate. Therefore, foreign exchange risks of the domestic currency against the U.S. dollar would be doubled, whereas foreign exchange risks of domestic currency against the yen would be halved under the currency basket peg system.

\subsubsection{Results of the Simulation Analysis}

Figures 5.14 through 5.18 show results of the simulation analysis for the capital inflows to each of the three countries. Movements in simulated values as well as actual values and estimated values of capital inflows are depicted in these figures. Estimated values are calculated by using the regression equations (1b), (1e), (1g), (1i), and (1k). Simulated values under the currency basket peg system are compared with estimated values under the de facto dollar peg system.

Simulated values for the "other investments" of Thailand are calculated by substituting supposed values of the fluctuations and deviations of the exchange rates into the regression equations (1b), (2a), and (5a). Equations (1e) and (2a) are used to calculate simulated values for the "portfolio and other investments" of Thailand. Equations (1g), (1i), and (2b) are used for Korea. Equations (1k), (2c), (3a), and (4a) are used for Indonesia.

In the cases of the "other investments" and the "portfolio and other investments" of Thailand, the simulated values of capital inflows are

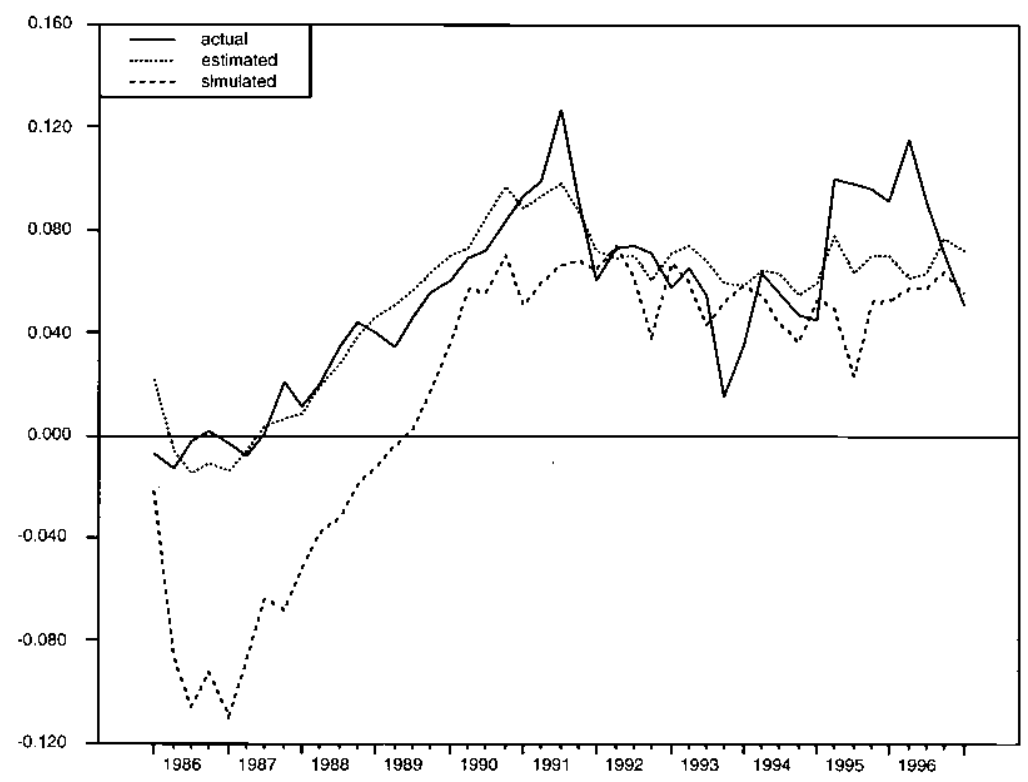

Fig. 5.14 Other investments: Thailand (ratio against GDP) 


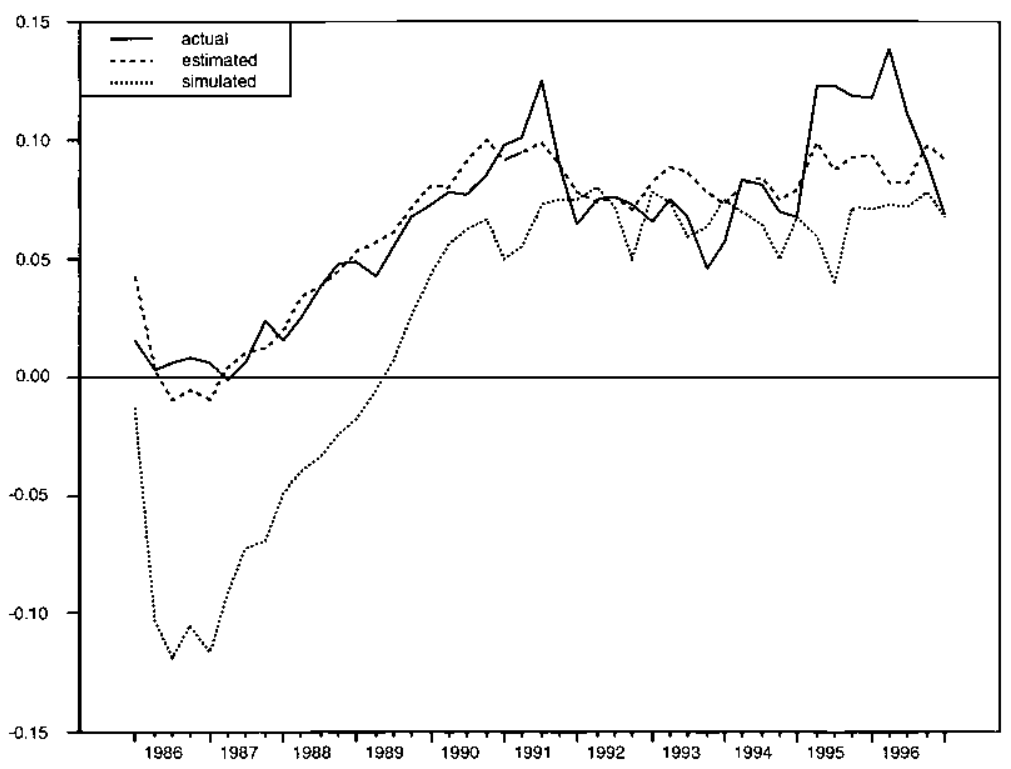

Fig. 5.15 Portfolio and other investments: Thailand (ratio against GDP)

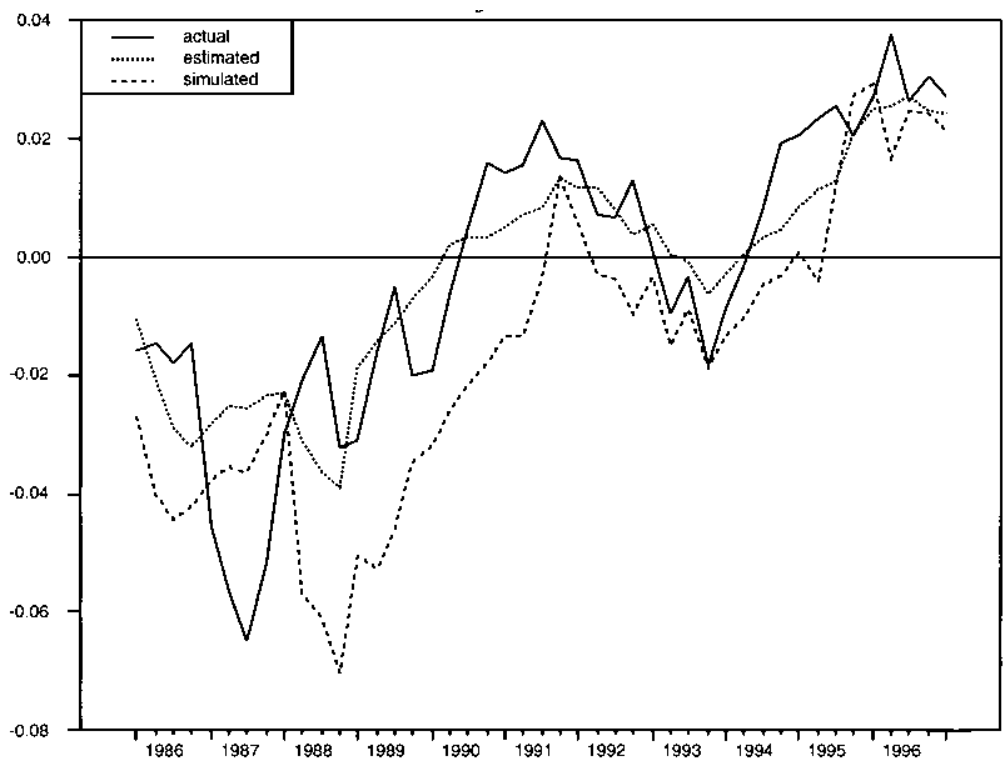

Fig. 5.16 Other investments: Korea (ratio against GDP) 


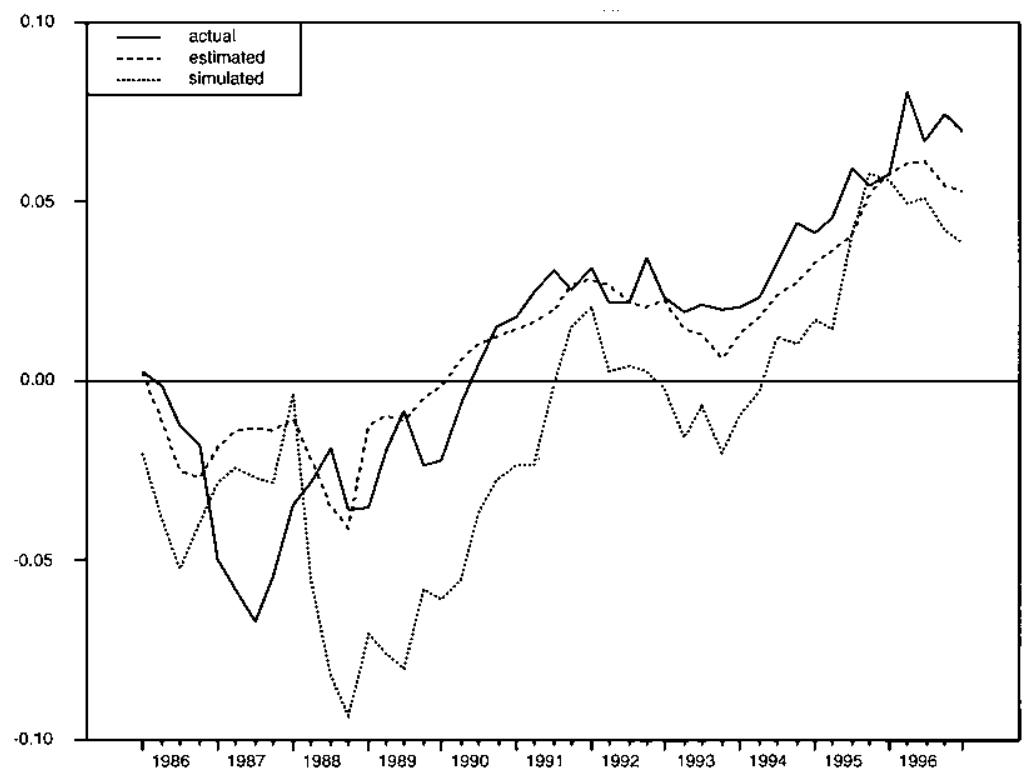

Fig. 5.17 Portfolio and other investments: Korea (ratio against GDP)

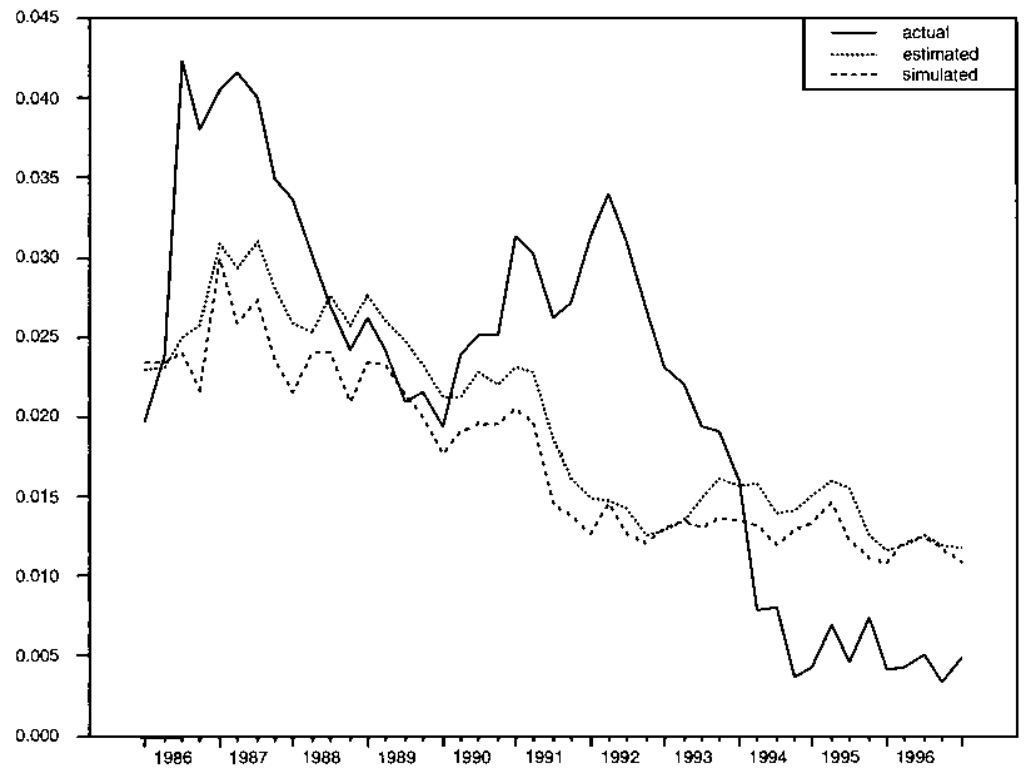

Fig. 5.18 Other investments: Indonesia (ratio against GDP) 
Table 5.5 Means and Standard Errors of Estimated and Simulated Values for Thailand, Korea, and Indonesia

\begin{tabular}{|c|c|c|c|c|c|}
\hline \multirow[b]{2}{*}{ Capital Flows } & \multicolumn{2}{|c|}{ Thailand } & \multicolumn{2}{|c|}{ Korea } & \multirow{2}{*}{$\begin{array}{c}\text { Indonesia } \\
\begin{array}{c}\text { Other } \\
\text { Investments }\end{array}\end{array}$} \\
\hline & $\begin{array}{c}\text { Other } \\
\text { Investments }\end{array}$ & $\begin{array}{l}\text { Portfolio } \\
\text { and Other } \\
\text { Investments }\end{array}$ & $\begin{array}{c}\text { Other } \\
\text { Investments }\end{array}$ & $\begin{array}{l}\text { Portfolio } \\
\text { and Other } \\
\text { Investments }\end{array}$ & \\
\hline \multicolumn{6}{|l|}{ 1986Q1-1997Q1 } \\
\hline estimated & $\begin{array}{c}0.0528 \\
(0.0318)\end{array}$ & $\begin{array}{c}0.0646 \\
(0.0332)\end{array}$ & $\begin{array}{c}-0.0025 \\
(0.0182)\end{array}$ & $\begin{array}{c}0.0116 \\
(0.0264)\end{array}$ & $\begin{array}{c}0.0195 \\
(0.0060)\end{array}$ \\
\hline simulated & $\begin{array}{c}0.0178 \\
(0.0558)\end{array}$ & $\begin{array}{c}0.0237 \\
(0.0633)\end{array}$ & $\begin{array}{r}-0.0164 \\
(0.0251)\end{array}$ & $\begin{array}{c}0.0140 \\
(0.0393)\end{array}$ & $\begin{array}{c}0.0175 \\
(0.0053)\end{array}$ \\
\hline \multicolumn{6}{|l|}{ 1990Q1-1997Q1 } \\
\hline estimated & $\begin{array}{c}0.0720 \\
(0.0118)\end{array}$ & $\begin{array}{c}0.0856 \\
(0.0086)\end{array}$ & $\begin{array}{c}0.0089 \\
(0.0095)\end{array}$ & $\begin{array}{c}0.0272 \\
(0.0178)\end{array}$ & $\begin{array}{c}0.0158 \\
(0.0036)\end{array}$ \\
\hline simulated & $\begin{array}{c}0.0544 \\
(0.0113)\end{array}$ & $\begin{array}{c}0.0653 \\
(0.0109)\end{array}$ & $\begin{array}{r}-0.0017 \\
(0.0166)\end{array}$ & $\begin{array}{c}0.0050 \\
(0.0316)\end{array}$ & $\begin{array}{c}0.0141 \\
(0.0028)\end{array}$ \\
\hline
\end{tabular}

Note: Numbers in parentheses are standard errors. Q1 = first quarter.

smaller than the estimated values during the analyzed period as shown in figures 5.14 and 5.15. Moreover, when we focus on the capital inflows in the 1990s, gaps between simulated and estimated values are large in 1991 and 1995 when surges of capital inflows to Thailand occurred.

Table 5.5 shows that means of simulated values are smaller than those of estimated values - especially, the simulated values of the "portfolio and other investments" are significantly smaller than the estimated values. Thus, it can be concluded that the currency basket peg system would have had a depressing effect on capital inflows to Thailand.

Figures 5.16 and 5.17 show the case of the "other investments" and the "portfolio and other investments" of Korea, respectively. The simulated values of capital inflows are smaller than the estimated ones during the analyzed period, except for some quarters in 1995. Table 5.5 also shows that means of simulated values are smaller than means of estimated values in Korea. Although the gaps are not as large as the gaps in Thailand, it still proves that the currency basket peg system would have had a depressing effect on capital inflows to Korea.

The actual capital inflows to Thailand were larger than the estimated values in both 1991 and 1995. The actual capital inflows were also larger than the estimated values during the period in 1996 for Korea. This fact implies that factors other than interest rates and foreign exchange risks had substantial effects on a surge of capital inflows during the mentioned period.

In the case of Indonesia, the simulated values of capital inflows were smaller than the estimated values during the analyzed period, although differences between them are small. Table 5.5 shows that means of simu- 
lated values are smaller than those of estimated values also in Indonesia, although they are not significantly different. Thus, the currency basket peg system would only have had a slightly depressing effect on capital inflows to Indonesia.

The results of the simulation imply that the currency basket peg system would have had a depressing effect on capital inflows to both Thailand and Korea and only a slightly depressing effect on capital inflows to Indonesia during the analyzed period.

\subsection{Conclusion}

East Asian countries that suffered the currency and financial crises had adopted a de facto dollar peg system. The de facto dollar peg system tended to extend fluctuations in trade balances of the countries as pointed out by Ito, Ogawa, and Sasaki (1998). In this paper, special attention is paid to the effect that the dollar peg system has on capital accounts. We empirically analyzed how the de facto dollar peg system stimulated capital inflows to Thailand, Korea, and Indonesia before the crises.

We conducted a simulation analysis of the impact on capital inflows to the countries under a currency basket peg system. From the regression analysis of the actual capital inflows, we found that responsiveness of capital flows to the foreign exchange risk against the U.S. dollar is much larger than responsiveness of capital flows to the foreign exchange risk against the yen in the case of Thailand and Korea. From the simulation analysis, we obtained the result that the currency basket peg system would have had a depressing effect on capital inflows to Thailand and Korea.

The asymmetry in the responsiveness to foreign exchange risks against the U.S. dollar and against the yen would have decreased capital inflows under the currency basket peg system. In other words, capital inflows were stimulated more through stable exchange rates against the U.S. dollar under the dollar peg system. Thus, we conclude that capital inflows would have been more stable under the currency basket peg system.

The following questions remains as an agenda for the future: What other factors explained the oversurges of the capital inflows? We tried to explain the oversurges of capital inflows using several explanatory variables, including export growth rate, stock prices, and the interest rates as well as the foreign exchange risks. Further attempts need to be made to discover other possible factors. Deregulation of capital inflows by the domestic monetary authorities is an important factor; we set it up as a deregulation dummy variable when estimating the capital flow equations. Other external factors such as speculative pressures from abroad may also be good candidates.

Another question is whether the coefficients in the capital flow equation could in fact be kept constant if the monetary authorities were to switch 
their exchange rate regime. In this paper, we assumed that they would be kept constant if the currency basket peg system were the one to be adopted in these countries. In addition, historical data and time series models were used to estimate the expected exchange rates and the foreign exchange risks. It implies that investors did not take into account the possibility of a future switch of regime when forming their expectations.

\section{References}

Bank for International Settlements (BIS). 1998a. Annual report. Basel, Switzerland: BIS.

. 1998b. International banking and financial market developments. Basel, Switzerland: BIS.

Calvo, Guillermo A., Leonardo Leiderman, and Carmen M. Reinhart. 1993. Capital inflows and real exchange rate appreciation in Latin America. IMF Staff Papers 40 (1): 108-51.

Calvo, Guillermo A., and Enrique G. Mendoza. 1996. Mexico's balance-ofpayments crisis: A chronicle of a death foretold. Journal of International Economics 41 (3/4): 235-64.

Dooley, Michael P. 1997. A model of crises in emerging markets. NBER Working Paper no. 6300. Cambridge, Mass.: National Bureau of Economic Research.

Demirgüç-Kunt, Asli, and Enrica Detragiache. 1997. The determinants of banking crises: Evidence from developing and developed countries. IMF Working Paper no. WP/97/106. Washington, D.C.: International Monetary Fund.

. 1998. Financial liberalization and financial fragility. IMF Working Paper no. WP/98/83. Washington, D.C.: International Monetary Fund.

Eichengreen, Barry, and Andrew K. Rose. 1998. Staying afloat when the wind shifts: External factors and emerging-market banking crises. NBER Working Paper no. 6370. Cambridge, Mass.: National Bureau of Economic Research.

Frankel, Jeffrey A., and Andrew K. Rose. 1996. Currency crashes in emerging markets: An empirical treatment. Journal of International Economics 41 (3/4): 351-66.

Frankel, Jeffrey A., and Shang-Jin Wei. 1994. Yen bloc or dollar bloc? Exchange rate policies of the east Asian economies. In Macroeconomic linkage: Savings, exchange rates, and capital flows, ed. Takatoshi Ito and Anne O. Krueger, 295392. Chicago: University of Chicago Press.

Goldfajn, Ilan, and Rodrigo O. Valdes. 1997. Capital flows and the twin crises: The role of liquidity. IMF Working Paper no. WP/97/87. Washington, D.C.: International Monetary Fund.

International Monetary Fund (IMF). 1997a. Exchange arrangements and exchange restrictions: Annual report. Washington, D.C.: IMF. . 1997b. International capital markets: Developments, prospects, and policy issues. Washington, D.C.: IMF.

1997c. World economic outlook: Interim assessment, Dec. 1997. Washington, D.C.: IMF.

1998. World economic outlook, May 1998. Washington, D.C.: IMF. 2000. International Financial Statistics CD-ROM. Washington, D.C.: IMF Publication Services. 
Ito, Takatoshi. 1999. Capital flows in Asia. NBER Working Paper no. 7134. Cambridge, Mass.: National Bureau of Economic Research.

Ito, Takatoshi, Eiji Ogawa, and Yuri N. Sasaki. 1998. How did the dollar peg fail in Asia? Journal of the Japanese and International Economies 12 (4): 256-304.

Kaminsky, Graciela, Saul Lizondo, and Carmen M. Reinhart. 1997. Leading indicators of currency crises. IMF Working Paper no. WP/97/79. Washington, D.C.: International Monetary Fund.

Kawai, Masahiro. 1997. East Asia currency turbulence: Implications of financial system fragility. A paper prepared for a seminar at the World Bank, Washington, D.C., November.

Kawai, Masahiro, and Shigeru Akiyama. 1998. The roles of the world's major currencies in exchange rate arrangements. Journal of the Japanese and International Economies 12 (4): 334-87.

Krugman, Paul. 1987. Pricing to market when the exchange rate changes. In Realfinancial linkages among open economies, ed. Sven W. Arndt and J. David Richardson, 49-70. Cambridge: MIT Press.

Marston, Richard C. 1990. Pricing to market in Japanese manufacturing. Journal of International Economics 29 (3/4): 217-36.

Miller, Victoria. 1996. Speculative currency attacks with endogenously induced commercial bank crises. Journal of International Money and Finance 15 (3): 383-403.

Velasco, Andres. 1987. Financial crises and balance of payments crises: A simple model of the southern cone experience. Journal of Development Economics 27 (1/2): $263-83$.

\section{Comments Francis T. Lui}

The main issue raised by Ogawa and Sun is what would have happened to capital inflows in Thailand, Indonesia, and Korea had they adopted a basket peg system. These countries had adopted a de facto dollar peg during the sample period, but Japanese bank loans to them were significantly higher than those from the United States. It seems to make sense if their currencies were at least partially pegged to the yen. From the policy perspective, it is therefore of interest to measure the effects on capital inflows if the Japanese yen had a larger weight in determining the exchange rates in these countries.

The authors have proceeded in two steps to answer this question: one step based on regression analysis, the other on counterfactual simulations. There are therefore two sets of results that need to be discussed.

The authors first attempt to measure the effects of several determinants of capital inflows (as a share of GDP). These include, among others, the home country's interest rate, exchange rate-adjusted U.S. interest rate, exchange rate-adjusted Japanese interest rate, and foreign exchange risks of

Francis T. Lui is professor of economics at the Hong Kong University of Science and Technology. 